\title{
The Archaeo-mineralogy of the Bronze Age Ceramics from Kul Tepe of Ajabshir, Eastern Lake Urmia Basin, Iran
}

\author{
Zeinab Nourzehi ${ }^{1}$, Bahram Ajorloo ${ }^{* 2}$, Masoud B. Kasiri ${ }^{3}$, Ghader Ebrahimi ${ }^{4}$ \\ ${ }^{1}$ MA in Archaeometry, Tabriz Islamic Art University, Tabriz, IRAN \\ ${ }^{2,3}$ Associate Professor, Faculty of Applied Arts, Tabriz Islamic Art University, Tabriz, IRAN \\ ${ }^{4}$ Ph.D. Candidate in Archaeology, University of Mohaghegh Ardebili, Ardebil, IRAN
}

\begin{abstract}
In the Bronze Age Archaeology of Northwestern Iran (plateau), the advent of various types of handmade gray-black ceramics shows the arrival of the so-called Kura-Araxian culture. The Urmia Ware, dating to the Late Bronze Age, on the other hand, represents the revival of the buff painted pottery tradition, following the decline of the Early Bronze Kura-Araxian culture. The present work attempted to examine the matrixes of samples of sherds in the Early Bronze gray-black pottery of Kura-Araxes, and a further samples of sherds in the Late Bronze buff-painted pottery of Urmian Ware, all collected during the surface surveys of Kul Tepe, Ajabshir County, through the Petrographic technique and observing thin-sections by polarizing microscope, as well as XRD and FT-IR analysis. The main objective was to study the similarities in the structure of the Early Bronze (Kura-Araxian) and Late Bronze (Urmian Ware) ceramics. The primary focus was on examining the possibility of local production of these ceramics through the analysis of the prepared thin-sections and ascertaining their technology, structure and composition, as well as gathering data on such fields as compositions and resources of raw material. Since Kul Tepe contains both Early Bronze and Late Bronze deposits, it offers a good opportunity for studying Archaeometrically the problem of discontinuity in technological pottery traditions, and the fact that whether the Urmian Ware tradition represented a local or an imported phenomenon. Results of the polarization microscopy, as well as the XRD and FT-IR analyses and their comparison to the available regional petrographic indices, showed that the clay used in both samples was procured from a single source, and the Early Bronze Age sherds and the Late Bronze Age painted sherds were then both manufactured locally.

Keywords: Kul Tepe of Ajabshir, Kura Araxian pottery, Urmian Ware, Petrography, XRD, FT-IR.
\end{abstract}

*Corresponding author: ajorloo@tabriziau.ac.ir 


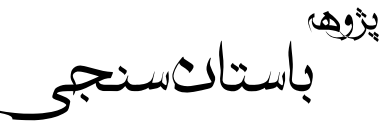

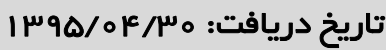

مقاله يُزوهشى

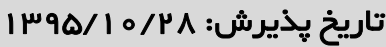

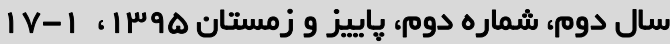

\section{باستان كانىشناسى سفالينههاى عصر مفرغ كؤلتيهُ عجبشير، شرق درياجةهُ اروميه}

زينب نورزهى '، بهر ام آجورلوّ"، مسعود باقرزاده كثيرى '، قادر ابراهيمى'

ا ا. كارشناس ارشد باستانسنجى دانشخاه هنر اسلامى تبريز، تبريز، ايران

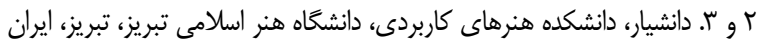

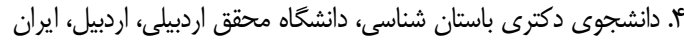

جكيده

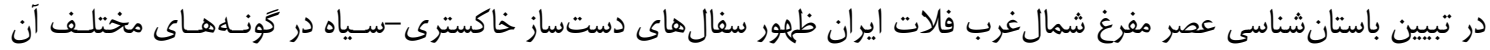

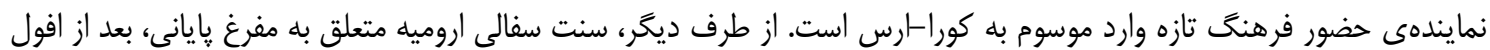

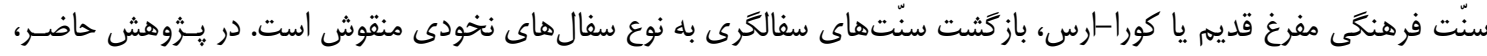

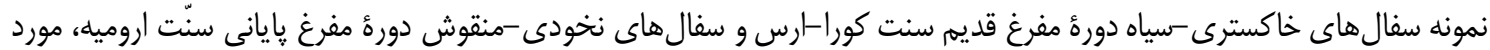

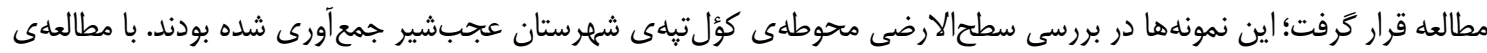

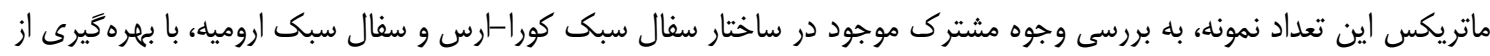

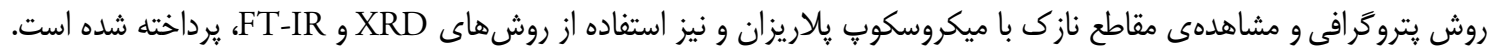

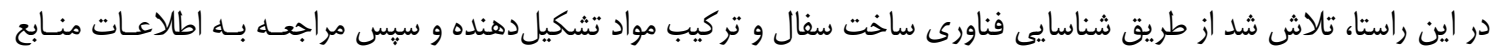

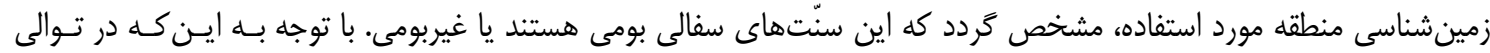

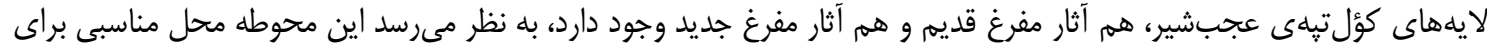

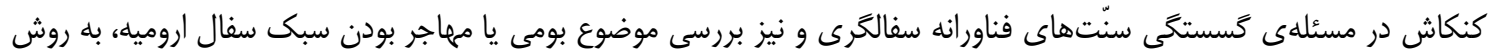

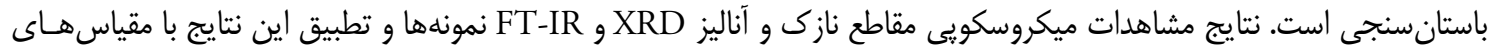

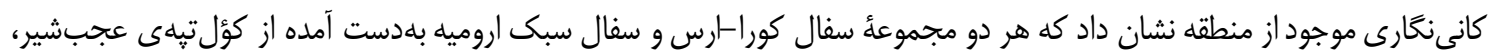

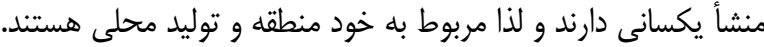

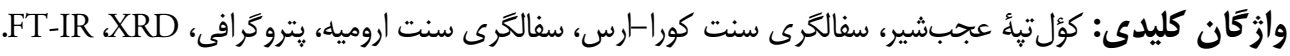

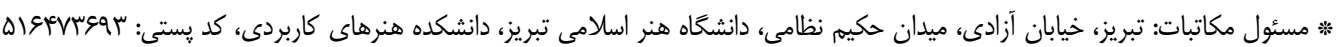
ajorloo@tabriziau.ac.ir يست الكترونيكى

(C) حق نشر متعلق به نويسنده(كان) است و نويسنده تحت مجوز Creative Commons Attribution License به مجله اجازه مى دهد مقاله جاب شده

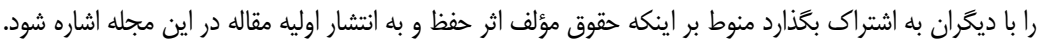


ماقبـل آن بــه بررسـى وجوهــات متفــاوت و مشـــرك ريزساختارى و همجٍنـين جنبـهـهـاى اشـتراك و افتـراق فناورى آنها يرداخته شده است.

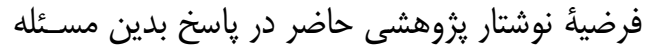

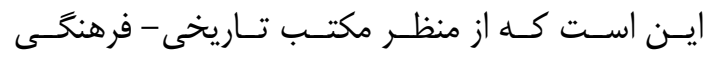
تفاوتهاى سبكشناختى و هنرى هر دو سنت مى استوانــ بر تفاوتهاى كانى شناختى و ريزساختارشناختى و فناورى

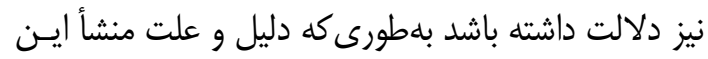
تفاوتهاى سبكشناختى و هنرى بر مهاجرت دلالت كند. همجنين رهيافت يزوهشى نويسندكان براى آز آزمودن

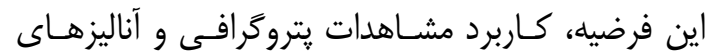
FT-IR و مجموعهاى از قطعات سفالى هر دو سنت در كؤلتبئ عجبشير بوده است.

\section{r. بيشينه يزوهش}

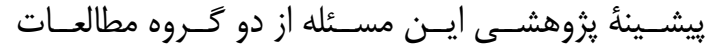
باستانشناختى و باستانسنجى شكل كرفته است: بـراى

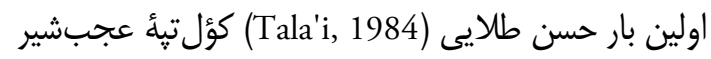
را با نام كلتته شناسايى و معرفى كرد؛ كه نويسندكان در

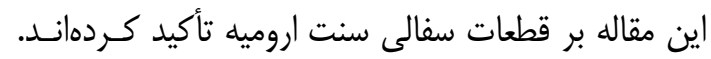
هي از كاوش هاى جارلز برنى در لايههاى ســنت كـوراارس و سنت ظروف نوع اروميه در يانيقتيه و هفتوانتيهـ (Burney \& Lang, 1972)

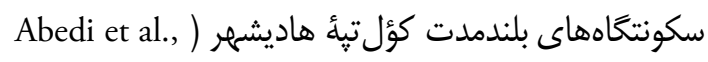

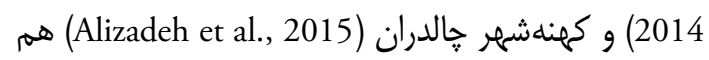
كزارش شده است كه البته كاوشكَران به مسئلة مهاجرت

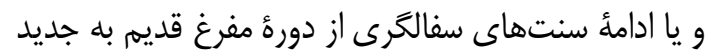
نيرداختهاند. در زمينأ باستانسنجى هم بايد اشاره شود كه

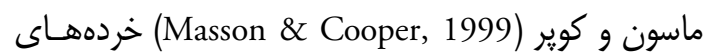

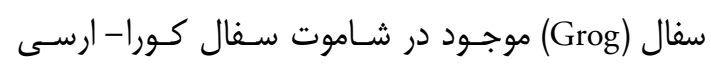

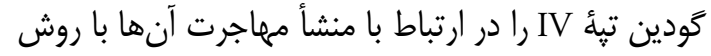

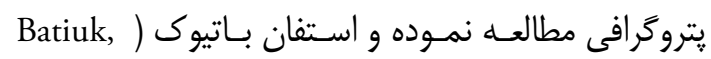
2000) مسئلة مقياس توليد خانگى را در مجموعأ كـورا-

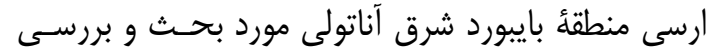

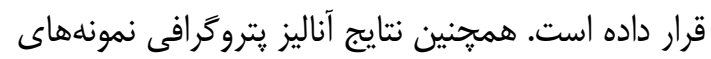
سؤس هؤيؤك در شرق تركيه بر توليد محلى سفالينههاى كورا- ارسى تأكيد كرده است (Kibaroğlu et al., 2011).

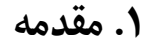

سفالكرى عصر مفرغ آذربايجان و شمال غرب فلات ايران

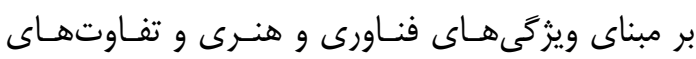

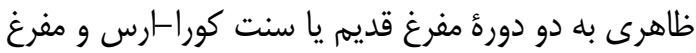

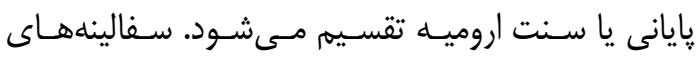

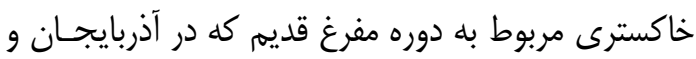
قفقاز موسوم به فرهنَ كورا-ارس است، از اواخــر هـز ارهـ

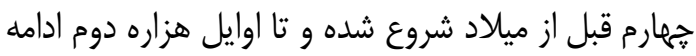

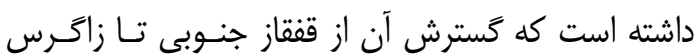
مركزى و از دشت الازيق در آناتولى مركزى تا دشت رى إنى و ورامين در شمال مركزى فلات ايران اسـت ( Ajorloo,

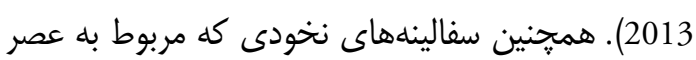

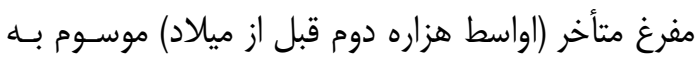

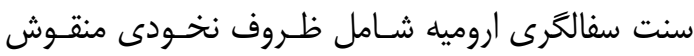

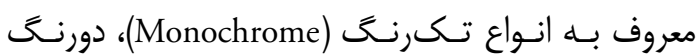
Tala'i, ) (Bichrome) 2004). از كؤلتئه عجبشير كه در شرق درياجهُ اروميـهـ

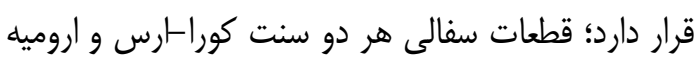

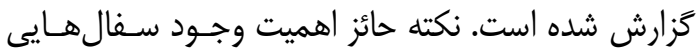

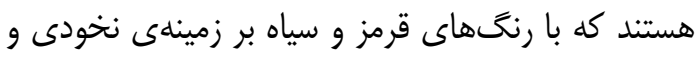

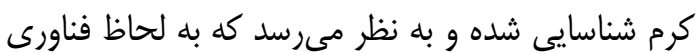

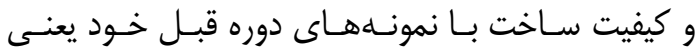
نمونههاى كورا -ارس متفاوت است. بــه درسـتى دانسـته

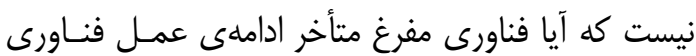
سفالكرى مفرغ قديم است يا خير. با توجه به بحث نظريئ

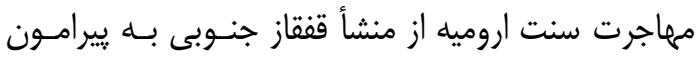

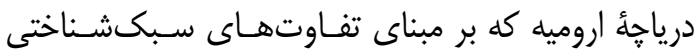
سفالكرى كورا-مارسى و سنت اروميه و نيز نظريهى مـونج

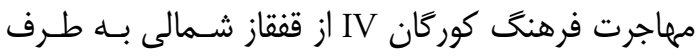
Burney \& Lang, 1972; ) قفقاز جنوبى مطرح شده است فرهن (Ajorloo, 2012 ويزگى هاى كانىشناختى و ريزساختارشناختى نمونههـاى

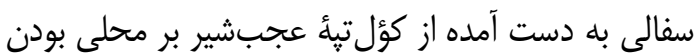

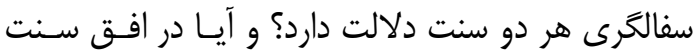

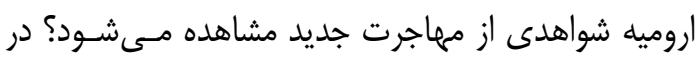

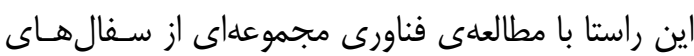

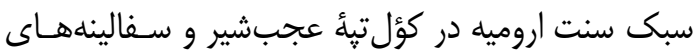


قطعه سفال نخودى - منقوش دوره مفــرغ پِايـانى ســنـت

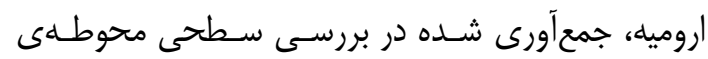

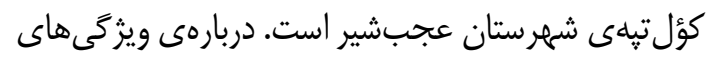

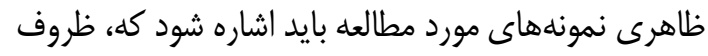

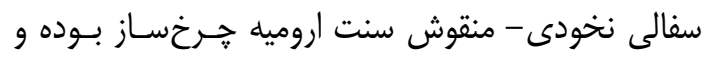

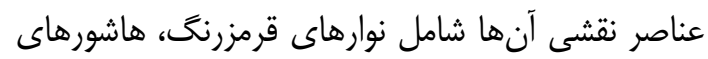
متقاطع، طرحهاى شطرنجى، يرندكان، حيوانـات جهاريا،

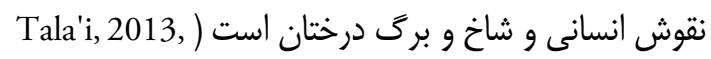

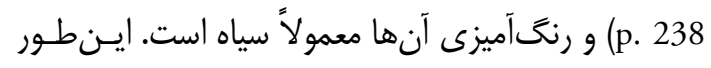

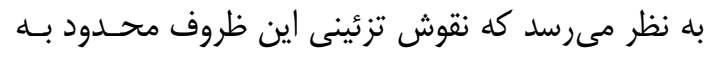

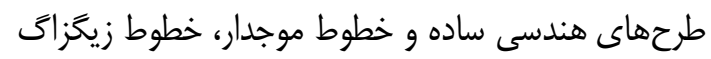

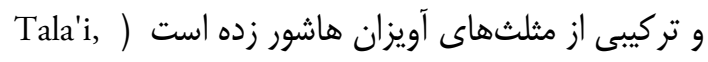

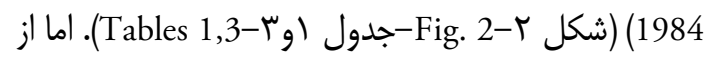
ويثگى هاى شاخص سنت سفالترى كورا- ارس مى توان

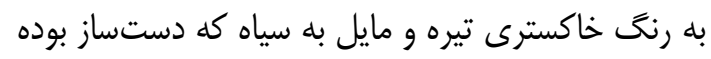

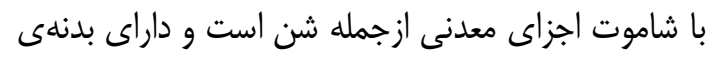

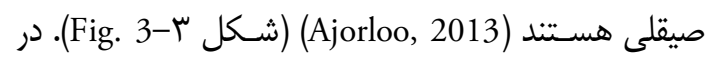
جدول شماره r و أ علاوه بر مشخصات ظاهرى نمونهها،

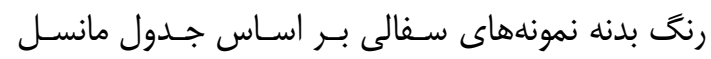

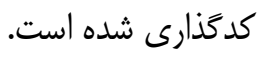

\section{r-r-r. روش تحقيق}

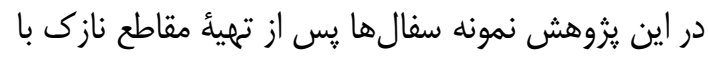

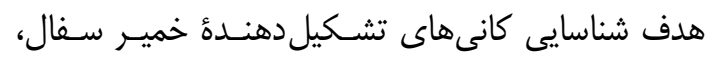

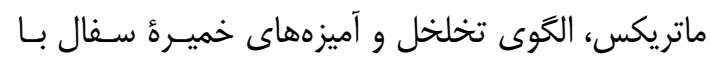

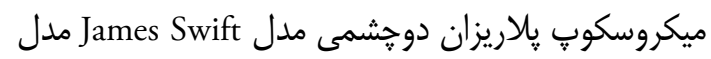
ساخت كشور زاين در آزمايشگاه

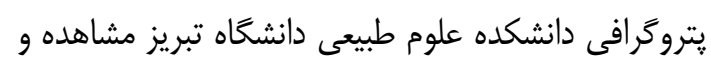

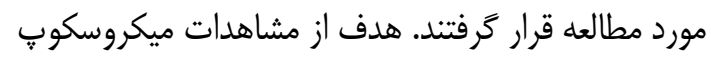
يلاريزان شناسايى كانىهاى تشكيل دهندهى بافت سفال

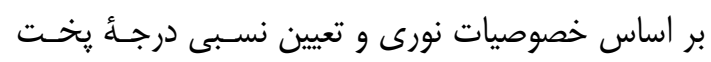

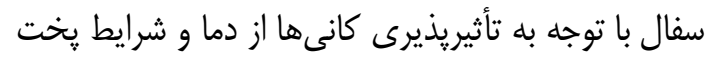

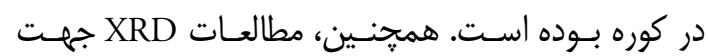
شناخت فازهاى كريستالين در بافت سفال توسط دستخاه

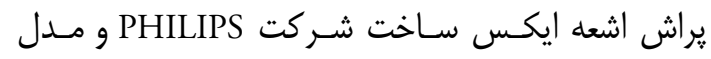

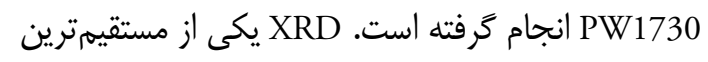

كمـا ايـنــــهـ مطالعـات باسـتان ســنجى افشــارىنـرزاد

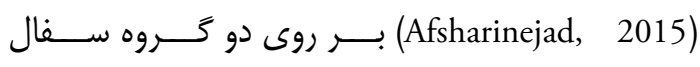

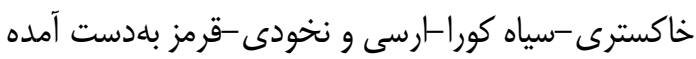

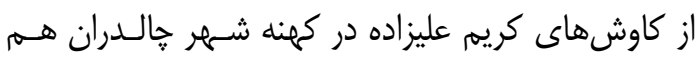
توليد محلى را نشان مى دهد.

\section{". معرفى محوطه كولتيه عجبشـير از منظــر جغر افيايى و زمينشناختى محوطه}

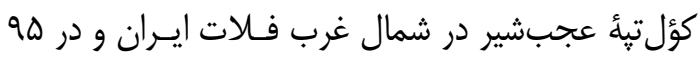

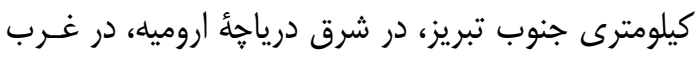

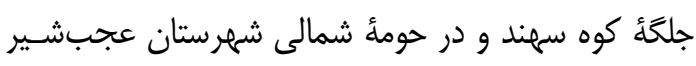

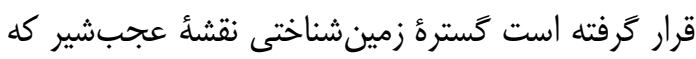

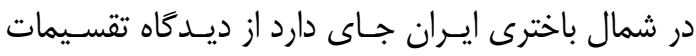

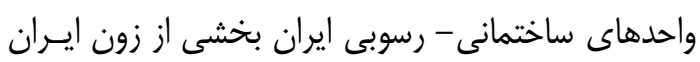

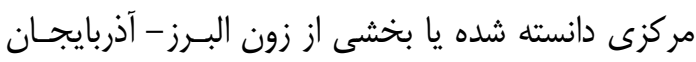

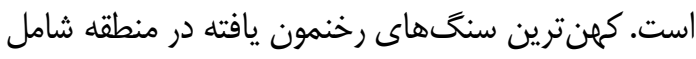

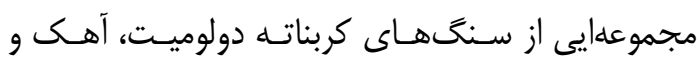

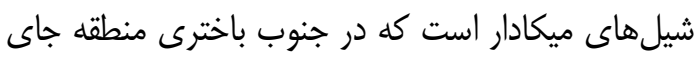

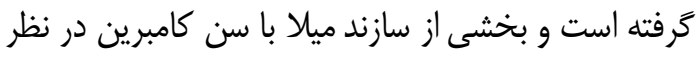

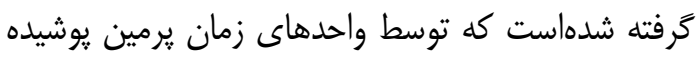

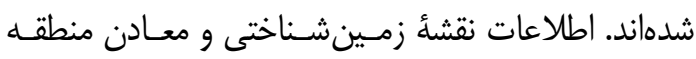

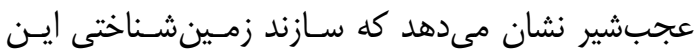

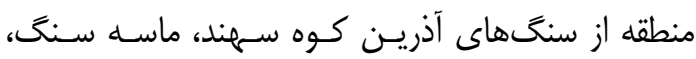

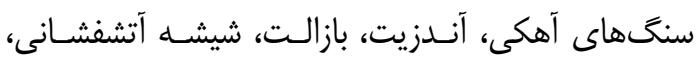

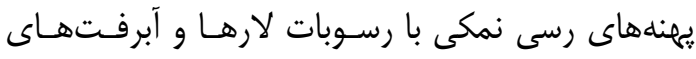

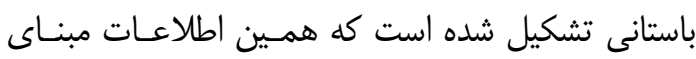

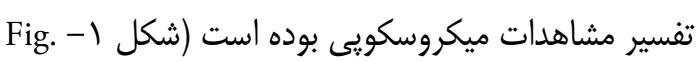

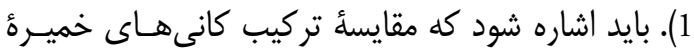

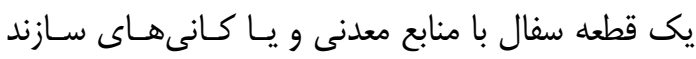

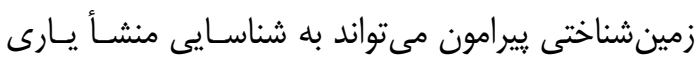
كند (Stuart, 2007).

\section{f. Pواد و روش هاى مورد مطالعه

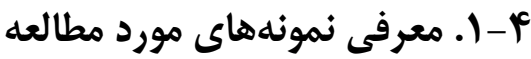

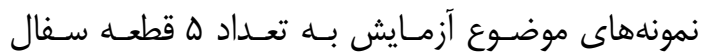

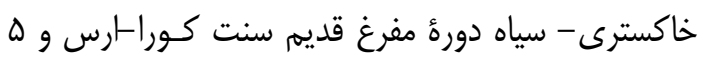




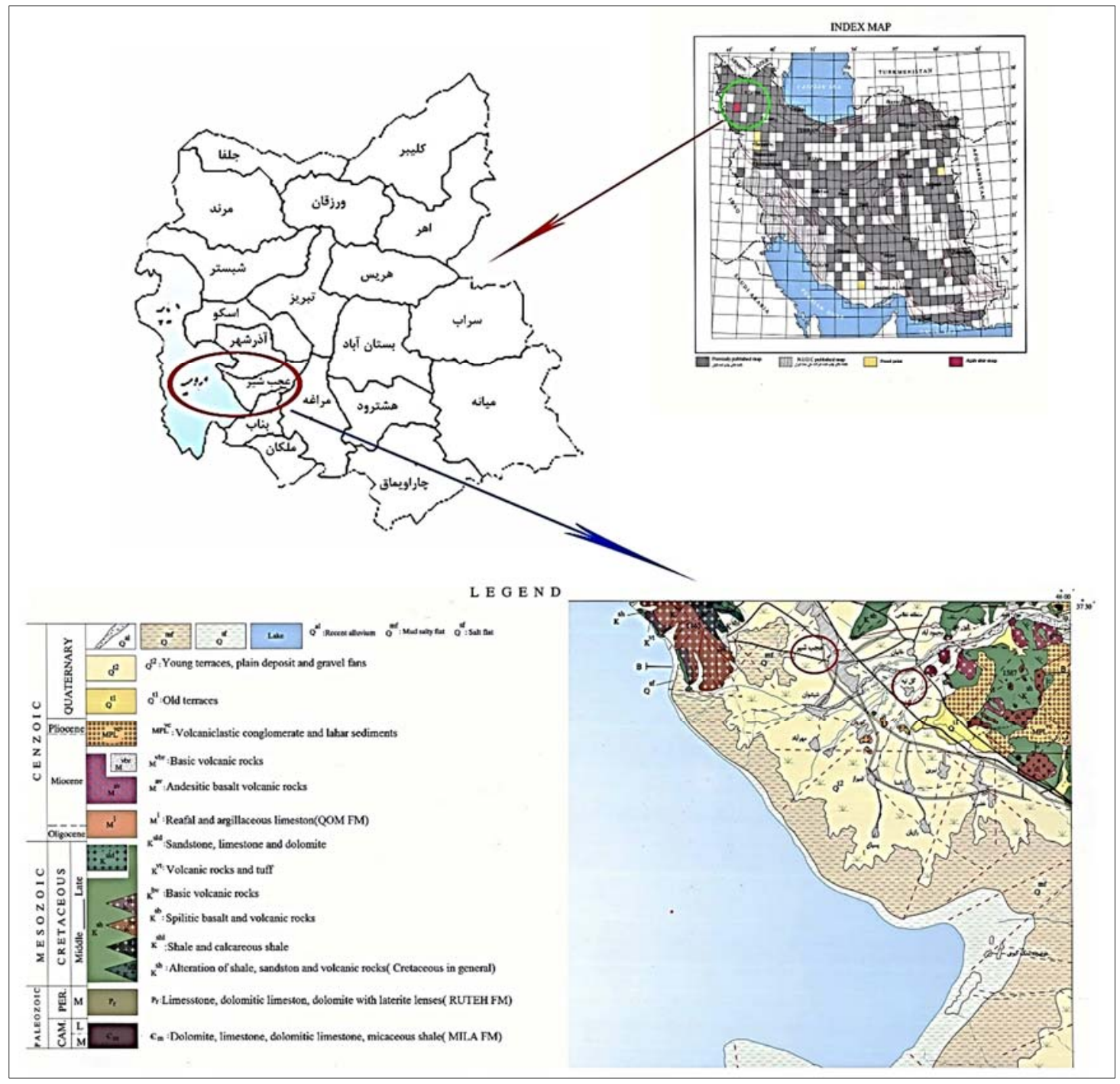

شكل ا: موقعيت قراركيرى منطقه عجبشير بر روى نقشه زمينشناسى و سازند زمينشناسى آن (ماخذ: انتشارات سازمان زمينشناسى و اكتشافات معدنى كشور)

Fig. 1: The location on the map geology and geological formation of the area Ajabshir (Geological Survey Publications of Iran)

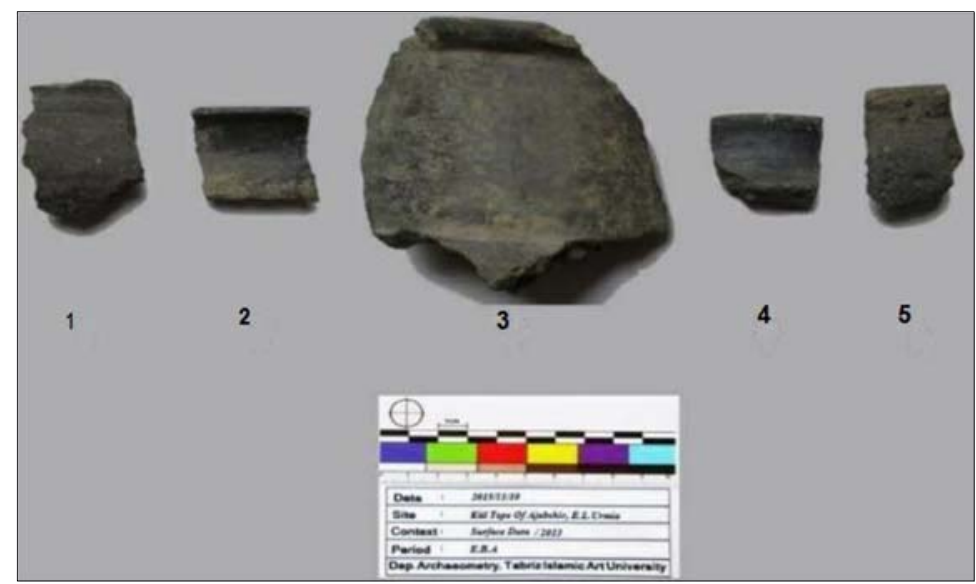

شكل ז: نمونه سفال هاى خاكسترى سياه سنت كورا-رارس محوطهى كؤلتبه عجبشير

Fig. 2: gray -black samples Kura-Araxes Kul Tepe of Ajabshir

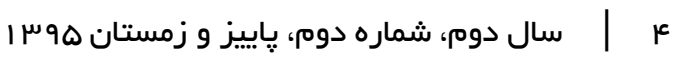


جدول (: رسم فنى نمونه سفالهاى خاكسترى سياه سنت كورا-رس محوطهى كؤلتيه عجبشير

Table 1: Illustrated samples of gray- black Kura-Araxes Kul Tepe of Ajabshir

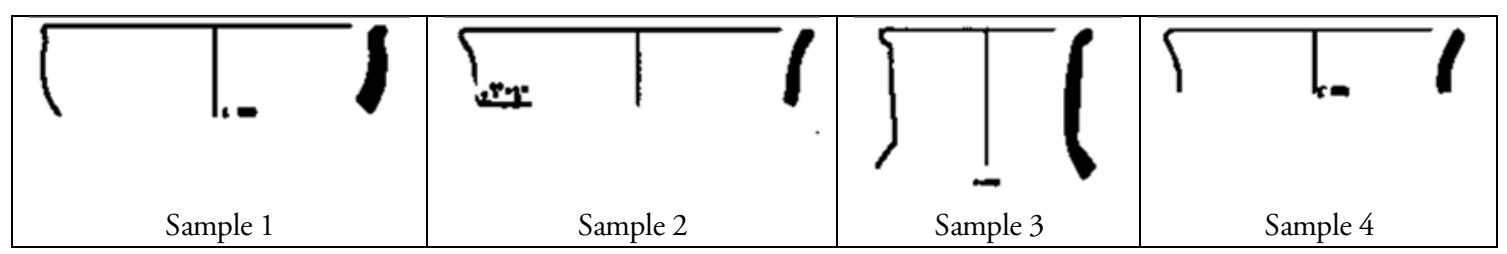

همانند ساختار سنَكَها، كانىهـاى مـورد اسـتفاده بـراى

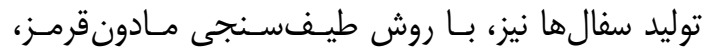

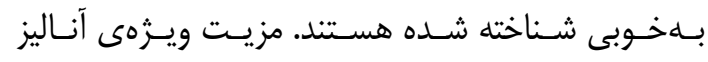
طيفسنجى مادونقرمز، نياز به نمونهى بسيار كم در حد

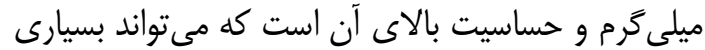

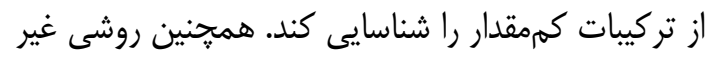

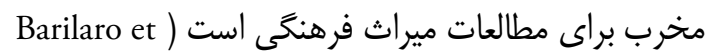

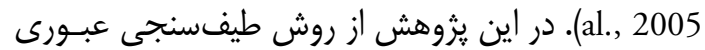
cm مر محدوده طيفى (Transmission Spectroscopy)

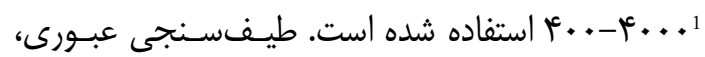
روش رايج در نمونهبردارى مادونقرمز است. با اين روش

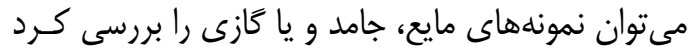

.(Stuart, 2007)
روشهاى شناسايى محتواى كـانى آثـار سـالى بـوده و مىتواند جهت بررسى مواد افزودنى و ماتريكس بــــ كـار

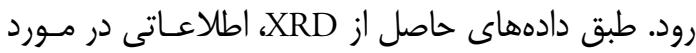

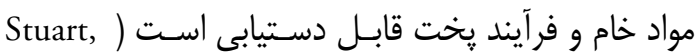

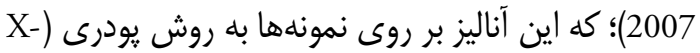
(ray powder diffraction كريستالين بهدست آمده با اسـتفاده از نـرمافـزار High Score

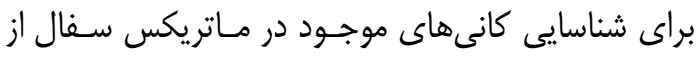

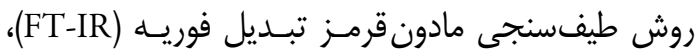

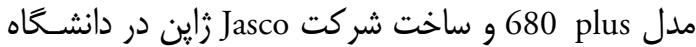
هنر اسلامى تبريز استفاده شد. طيفسنجى مادون قرمكـز براى شناسايى كانىهاى موجود در سفالها به كار ميروداد.

جدول r: مشخصات ظاهرى نمونه سفال هاى سياه-خاكسترى مورد مطالعه محوطه كؤلتبه عجبشير

Table 2: Specification appearance of gray- black pottery samples from Kul Tepe of Ajabshir

\begin{tabular}{|c|c|c|c|c|c|c|c|c|c|c|c|}
\hline \multirow{2}{*}{$\begin{array}{c}\text { شمونهارها } \\
\text { Sample no. } \\
\text { Sample }\end{array}$} & \multirow{2}{*}{$\begin{array}{c}\text { كد رنغَ بدنه } \\
\text { Munsell } \\
\text { code }\end{array}$} & \multicolumn{3}{|c|}{ رنى Color } & \multirow{2}{*}{$\begin{array}{c}\text { يخت } \\
\text { Firing }\end{array}$} & \multirow{2}{*}{$\begin{array}{l}\text { يوشش } \\
\text { Coating }\end{array}$} & \multirow{2}{*}{$\begin{array}{c}\text { تزئينات } \\
\text { Decoration }\end{array}$} & \multirow{2}{*}{$\begin{array}{l}\text { نوع قطعه } \\
\text { Sherd type }\end{array}$} & \multirow{2}{*}{$\begin{array}{c}\text { بستر } \\
\text { Context }\end{array}$} & \multirow{2}{*}{$\begin{array}{c}\text { محوطه } \\
\text { Site }\end{array}$} & \multirow{2}{*}{$\begin{array}{c}\text { ضخامت } \\
\text { Th. (mm) }\end{array}$} \\
\hline & & $\begin{array}{c}\text { بيرون } \\
\text { exterior }\end{array}$ & خميره & $\begin{array}{c}\text { درون } \\
\text { interior }\end{array}$ & & & & & & & \\
\hline 1 & $\mathrm{~N} 1 / 2$ & سياه & خاكسترى / & سياه & $\begin{array}{l}\text { High } \\
+800^{\circ} \mathrm{C}\end{array}$ & دست مرطوب & - & $\begin{array}{l}\text { لبه } \\
\text { edge }\end{array}$ & $\begin{array}{l}\text { سطحى } \\
\text { Surface }\end{array}$ & $\begin{array}{c}\text { كولتيه } \\
\text { Kul Tepe }\end{array}$ & 10 \\
\hline 2 & $\mathrm{~N} 1 / 1$ & $\begin{array}{l}\text { سياه } \\
\text { black }\end{array}$ & خاكسترى & سياه & $\begin{array}{c}\text { High } \\
+800^{\circ} \mathrm{C}\end{array}$ & دست مرطوب & $\begin{array}{c}\text { نقش كنده } \\
\text { هندسى } \\
\text { Geometric } \\
\text { incised }\end{array}$ & $\begin{array}{c}\text { لبd } \\
\text { edge }\end{array}$ & $\begin{array}{l}\text { سطحى } \\
\text { Surface }\end{array}$ & $\begin{array}{c}\text { كولتيه } \\
\text { Kul Tepe }\end{array}$ & 7 \\
\hline 3 & $\mathrm{~N} 1 / 1$ & خاكسترى & خاكسترى / & خاكسترى & $\begin{array}{c}\text { Low } \\
-800^{\circ} \mathrm{C}\end{array}$ & دست مرطوب & - & $\begin{array}{l}\text { گردن } \\
\text { neck }\end{array}$ & $\begin{array}{l}\text { سطحى } \\
\text { Surface }\end{array}$ & $\begin{array}{c}\text { كولتيه } \\
\text { Kul Tepe }\end{array}$ & 11 \\
\hline 4 & $\mathrm{~N} 1 / 1$ & سياه & خاكسترى & سياه & $\begin{array}{l}\text { Low } \\
-800^{\circ} \mathrm{C}\end{array}$ & |دست مرطوب & - & $\begin{array}{l}\text { لبه } \\
\text { edge }\end{array}$ & $\begin{array}{l}\text { سطحى } \\
\text { Surface }\end{array}$ & $\begin{array}{c}\text { كولتيه } \\
\text { Kul Tepe }\end{array}$ & 9 \\
\hline 5 & $\mathrm{~N} 1 / 2$ & خاكسترى & $\begin{array}{c}\text { خاكسترى } \\
\text { Gray/ } \\
\text { Brown }\end{array}$ & $\begin{array}{c}\text { قهوايى سياه } \\
\text { Brown/ } \\
\text { black }\end{array}$ & $\begin{array}{c}\text { Low } \\
-800^{\circ} \mathrm{C}\end{array}$ & |دست مرطوب & - & $\begin{array}{l}\text { لبه } \\
\text { edge }\end{array}$ & $\begin{array}{l}\text { سطحى } \\
\text { Surface }\end{array}$ & $\begin{array}{c}\text { كولتيه } \\
\text { Kul Tepe }\end{array}$ & 13 \\
\hline
\end{tabular}




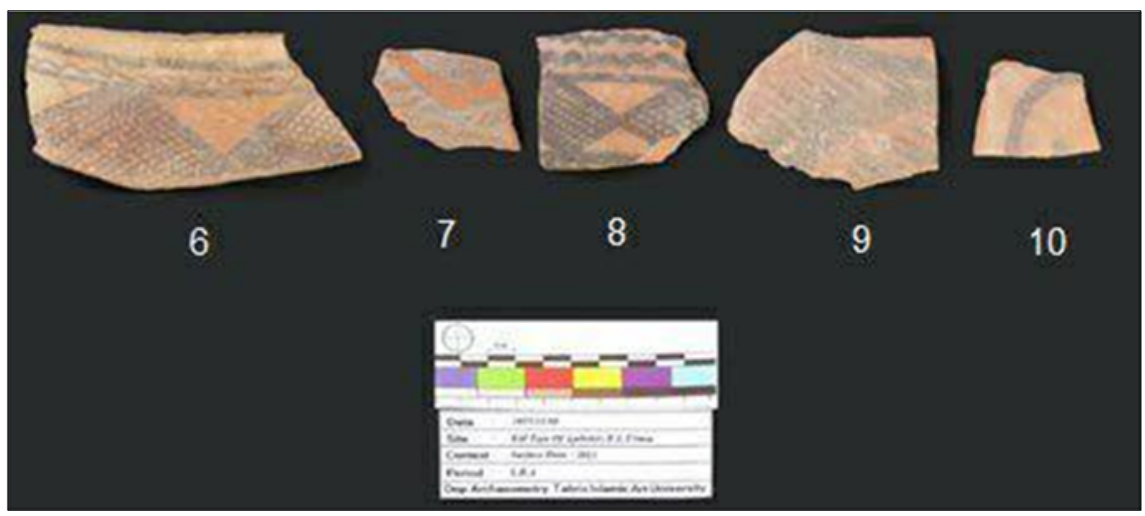

شكلس: نمونهاى نخودى -منقوش سنت اروميه محوطهى كؤلتيه عجبشير

Fig. 3: Buff-painted pottery of Urmian Ware from Kul Tepe of Ajabshir

جدول": رسم فنى نمونه سفال هاى نخودى - منقوش سنت اروميه محوطهى كؤلتِه عجبشير

Table 3: Illustrated samples of buff-painted pottery of Urmian Ware from Kul Tepe of Ajabshir

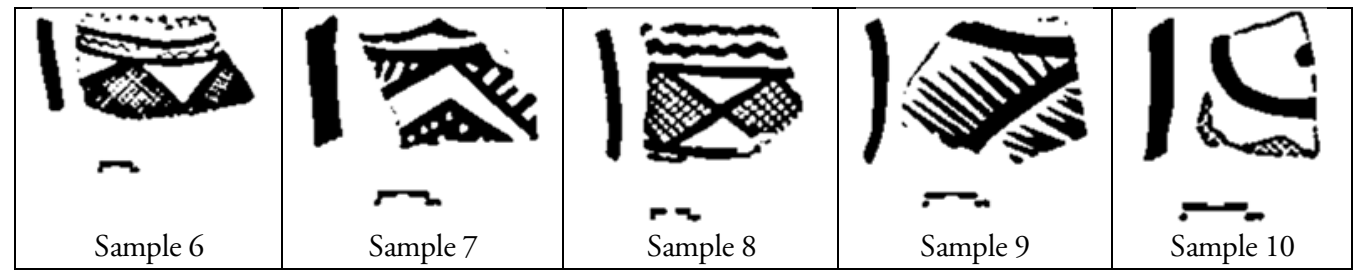

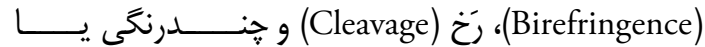

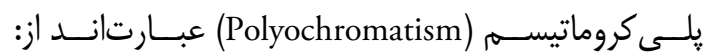

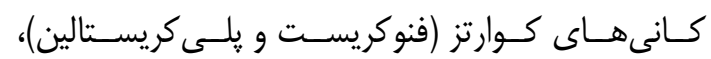

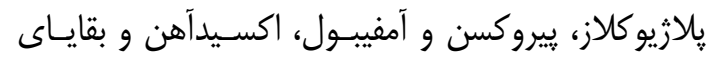

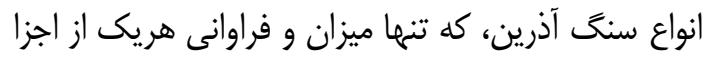

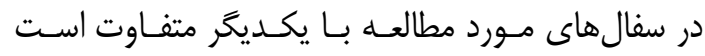

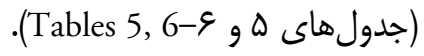

هـ آزمايشات و نتايج

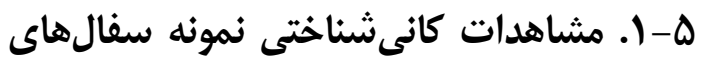

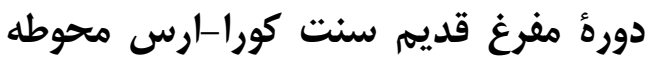

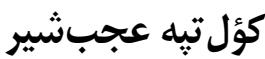

كانىهاى شاخص مشاهده شده در تمامى ه نمونه با توجه

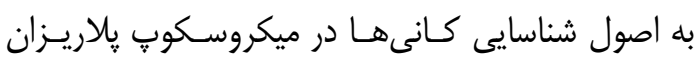

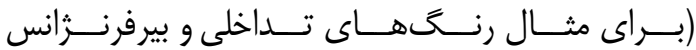

جدول أ: مشخصات ظاهرى نمونه سفال هاى نخودى - منقوش مورد مطالعه محوطه كؤلتيه عجبشير

Table 4: Specification appearance buff-painted pottery of Urmian Ware from Kul Tepe of Ajabshir

\begin{tabular}{|c|c|c|c|c|c|c|c|c|c|c|c|}
\hline \multirow{2}{*}{$\begin{array}{c}\text { شمونه هاره } \\
\text { Sample no. } \\
\text { Samplo }\end{array}$} & \multirow{2}{*}{\begin{tabular}{|c|} 
كد رنََ بدنه \\
Munsell code
\end{tabular}} & \multicolumn{3}{|c|}{ رنغ Color } & \multirow{2}{*}{$\begin{array}{l}\text { يخت } \\
\text { Firing }\end{array}$} & \multirow{2}{*}{ يوشش } & \multirow{2}{*}{$\begin{array}{c}\text { تزئينات } \\
\text { Decoration }\end{array}$} & \multirow{2}{*}{$\begin{array}{l}\text { نوع قطعه } \\
\text { Sherd type }\end{array}$} & \multirow[b]{2}{*}{$\begin{array}{c}\text { بستر } \\
\text { context }\end{array}$} & \multirow[b]{2}{*}{$\begin{array}{c}\text { محوطد } \\
\text { Site }\end{array}$} & \multirow[b]{2}{*}{ ضخامت } \\
\hline & & $\begin{array}{c}\text { بيرون } \\
\text { exterior }\end{array}$ & خميره & $\begin{array}{c}\text { دوون } \\
\text { interior }\end{array}$ & & & & & & & \\
\hline 6 & $5 Y R 7 / 5$ & $\begin{array}{c}\text { نخودى } \\
\text { Buff }\end{array}$ & قرمز & $\begin{array}{l}\text { قرمز } \\
\text { Red }\end{array}$ & $\begin{array}{l}\text { High } \\
+800^{\circ} \mathrm{C} \\
\end{array}$ & $\begin{array}{l}\text { دست مرطوب } \\
\text { Slip }\end{array}$ & $\begin{array}{l}\text { منقوش } \\
\text { painted }\end{array}$ & $\begin{array}{l}\text { neck } \\
\text { nرن }\end{array}$ & $\begin{array}{l}\text { سطحى } \\
\text { Surface }\end{array}$ & $\begin{array}{c}\text { كولتيه } \\
\text { Kul Tepe }\end{array}$ & 8 \\
\hline 7 & $5 Y R 7 / 6$ & قرمز & قرمز & $\begin{array}{c}\text { Buff } \\
\text { Buودى }\end{array}$ & $\begin{array}{l}\text { High } \\
+800^{\circ} \mathrm{C}\end{array}$ & $\begin{array}{l}\text { دست مرطوب } \\
\text { Slip }\end{array}$ & $\begin{array}{l}\text { منقوش } \\
\text { painted }\end{array}$ & $\begin{array}{c}\text { لب } \\
\text { edge }\end{array}$ & $\begin{array}{l}\text { سطحى } \\
\text { Surface }\end{array}$ & $\begin{array}{c}\text { كولتيه } \\
\text { Kul Tepe }\end{array}$ & 9 \\
\hline 8 & 5YR8/4 & قرمز & قرمز & قرمز & $\begin{array}{l}\text { High } \\
+800^{\circ} \mathrm{C} \\
\end{array}$ & $\begin{array}{c}\text { دست مرطوب } \\
\text { Slip }\end{array}$ & $\begin{array}{l}\text { منقوش } \\
\text { painted }\end{array}$ & $\begin{array}{c}\text { لب } \\
\text { edge }\end{array}$ & $\begin{array}{l}\text { سطحى } \\
\text { Surface }\end{array}$ & $\begin{array}{c}\text { كولتيه } \\
\text { Kul Tepe }\end{array}$ & 8 \\
\hline 9 & $5 Y R 8 / 3$ & قرمز & قرمز & قرمز & $\begin{array}{l}\text { High } \\
+800^{\circ} \mathrm{C} \\
\end{array}$ & $\begin{array}{l}\text { دست مرطوب } \\
\text { Slip }\end{array}$ & $\begin{array}{l}\text { منقوش } \\
\text { painted }\end{array}$ & $\begin{array}{c}\text { بدنd } \\
\text { shred }\end{array}$ & $\begin{array}{l}\text { سطحى } \\
\text { Surface }\end{array}$ & $\begin{array}{c}\text { كولتيه } \\
\text { Kul Tepe }\end{array}$ & 8 \\
\hline 10 & 5YR8/4 & $\begin{array}{l}\text { قرمز } \\
\text { Red }\end{array}$ & $\begin{array}{l}\text { قرمز } \\
\text { Red }\end{array}$ & قرمز & $\begin{array}{l}\text { High } \\
+800^{\circ} \mathrm{C}\end{array}$ & $\begin{array}{c}\text { دست مرطوب } \\
\text { Slip }\end{array}$ & $\begin{array}{l}\text { منقوش } \\
\text { painted }\end{array}$ & $\begin{array}{l}\text { بدنd } \\
\text { shred }\end{array}$ & $\begin{array}{l}\text { سطحى } \\
\text { Surface }\end{array}$ & $\begin{array}{c}\text { كولتيه } \\
\text { Kul Tepe }\end{array}$ & 7 \\
\hline
\end{tabular}


جدول ه: مشاهدات يتروگرافى سفال هاى خاكسترى سياه دورهى مفرغ قديم كؤلتيه عجبشير

Table 5: Petrographic observations of gray- black pottery Early Bronze Age, Kul Tepe of Ajabshir

\begin{tabular}{|c|c|c|c|c|c|c|c|c|c|c|c|}
\hline $\begin{array}{c}\text { Sample } \\
\text { no. }\end{array}$ & T exture & $\begin{array}{c}\text { Quartz } \\
\text { phenocrysts }\end{array}$ & $\begin{array}{c}\text { Quartz } \\
\text { polycrystalline }\end{array}$ & Plagioclase & $\begin{array}{l}\text { Pyroxene, } \\
\text { Amphibole }\end{array}$ & Mica & Hematite & $\begin{array}{l}\text { Second } \\
\text { Calcite } \\
\end{array}$ & $\begin{array}{c}\text { Volcanic } \\
\text { Rock }\end{array}$ & Glass & Grog \\
\hline 1 & Porphyry & $*$ & - & $*$ & * & - & * & tr & $*$ & - & * \\
\hline 2 & Porphyry & * & * & * & * & - & * & * & * & - & * \\
\hline 3 & Silt & * & * & * & * & - & * & * & * & - & * \\
\hline 4 & Porphyry & * & * & * & * & - & * & - & * & * & * \\
\hline 5 & Porphyry & * & * & * & * & * & * & * & * & - & - \\
\hline
\end{tabular}

فراوانى هر يكى از اجزا، تفاوتهايى ديده مسىشـود. ايـنـ نمونهها فاقد كلسيت بوده و تمامى سفال هاى مطالعاتى

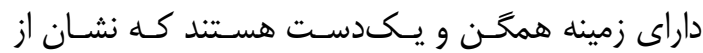

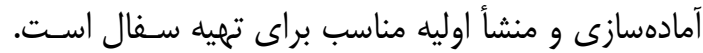
در نمونه شماره ب سفال نخودى -منقوش، كـانى كوارتز نوع يلى كريستالين فراوانس بيشـترى دارد كـه در ديخــر

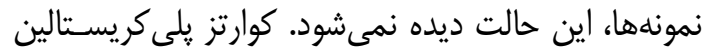

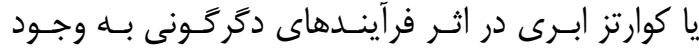

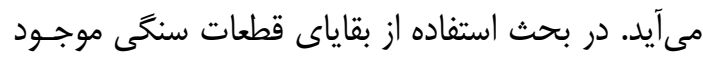

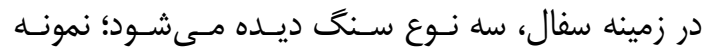

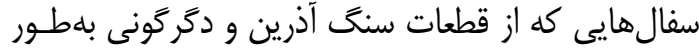

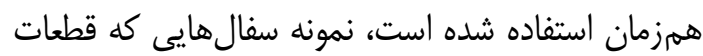

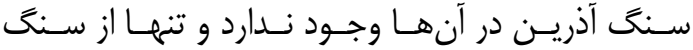

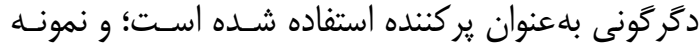

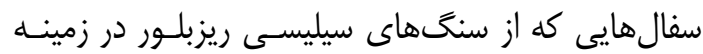

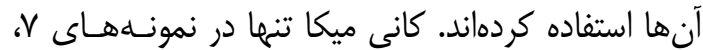
•ا سفال هاى سنت اروميه وجود دارد و در ديخر نمونهها. ديده نمى شود و فقـط در نمونـهـ شـماره 9 خـردهسـفال مشاهده شد (جدول 9-6 Table).

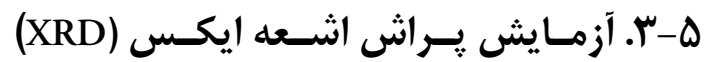

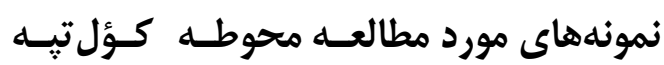

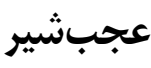

نتايج آزمايش يراش اشعهل ايكس بــر روى دو نمونسهى سياه-خاكسـترى سـنت كـورا-ارس و دو نمونـه سـفال نخودى -منقوش سنت اروميه بلهصورت فازهاى شناسايى

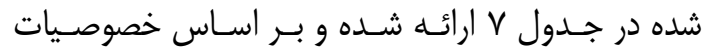
كريستالوكرافى هر كدام از نمونههـا مـورد بررسـى قـرار
از بين نمونه سفالهاى مـورد مطالعـه، نمونـههـاى شماره أ و ه فاقد كلسيت اوليه بوده و بقيه نمونهها دارى لهاي

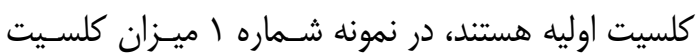
بسيار كم (tr) است. احتمالا عدم وجود كلسـيت در ايـن نمونها مشخص مى كند كه دماى يخت سفال از

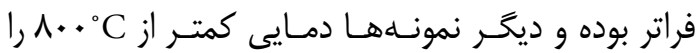

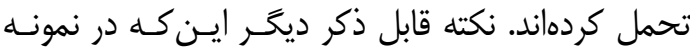

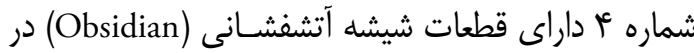

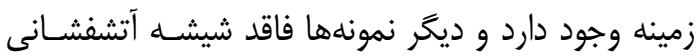
هستند. قطعات سفالى خردشده (Grog)، قطعات رسى يـا

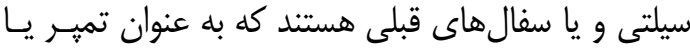

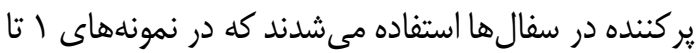

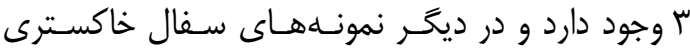
مطالعه شده ديده نمى شود. در نمونسه شـماره ب تشـكيل كلسيت ثانويه در ادامهى فرآيند كربناتيزاسيون، با شرايط ديط محيطى مناسب و حضـور دىاكسـيدكربن اتفـاق افتـاده است. تفاوت كلسيت ثانويه با فاز كربناته اوليـه، اخـتافلاف

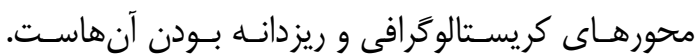
شايان ذكر است كه فازهاى ثانويه، تحـت تـأثير شـرايط محيطى، در حاشيه فازها و يا مكان مناسب جوانهزنسى در

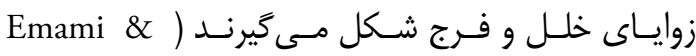

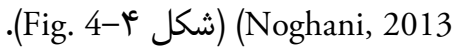

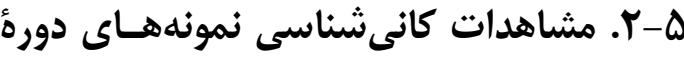 مفرغ جديد سنت اروميه محوطـهـ كـؤلتِيـهـ

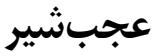

تمام ه قطعه سفال مورد بررسى از نظــر تركيـب و اجـزا

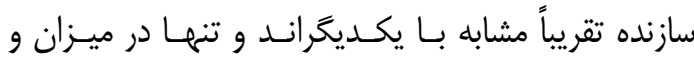

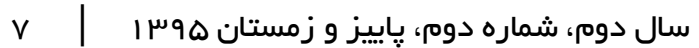


است. تحقيقات نشان داده اسـت كـه برخـى از فازهـاى

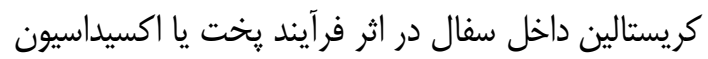

كرفت. زيرا شناسايى تغييرات كانىهاى سـازندهى بافت

داخلى سفال تنها با دانستن شرايط بايدارى هر فاز ممكن
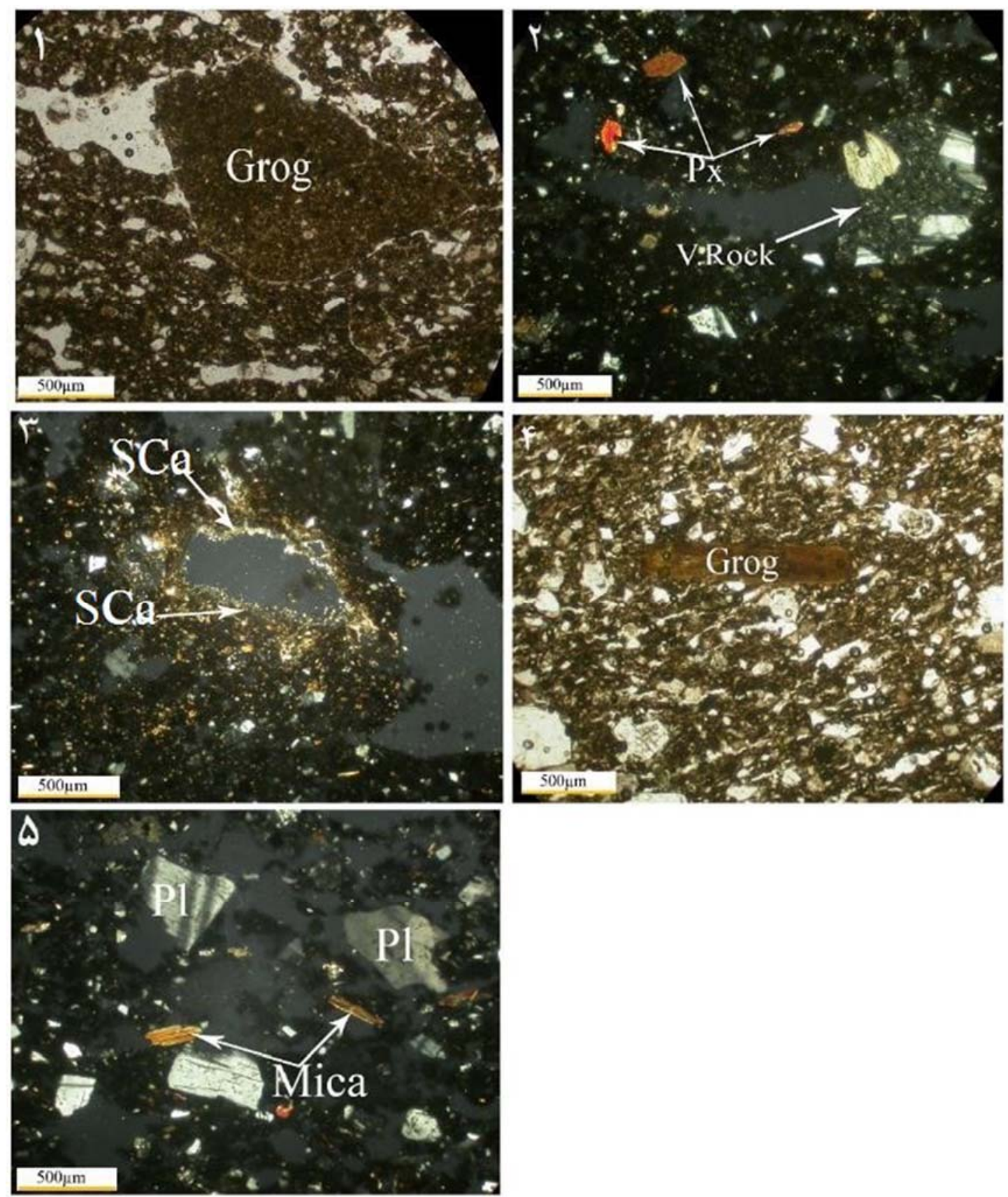

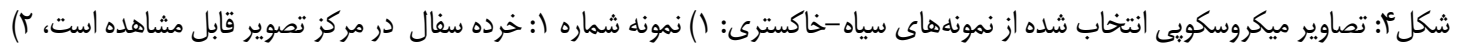

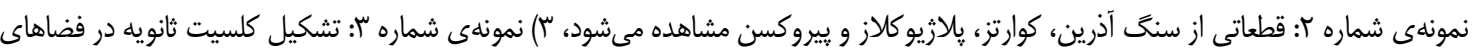

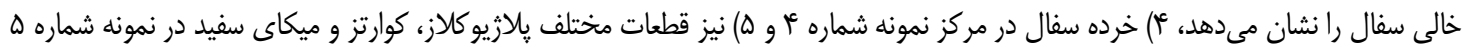

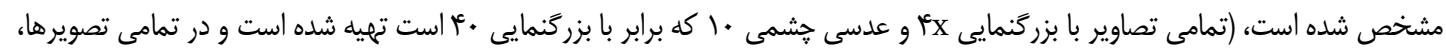

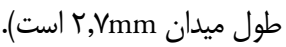

Fig. 4: Microscopic images selected from the Samples of gray- black: 1) Sample No.1. Grog in the pottery structure, 2) Sample No.2. V.rock, quartz, plagioclase and pyroxene, 3) Secondary calcite formation in space blank pottery, 4) Grog in the center of image and the different parts plagioclase, quartz and white mica in the sample. (All images Zoom is $x 4$ and that is 10 resisted by zooming eyepiece 40 is provided in the all images, field of view is $2.7 \mathrm{~mm}$ ). 
جدول \&: مشاهدات يتروگرافى سفال هاى نخودى - منقوش سنت اروميه محوطه كؤلتبه عجبشير

Table 6: Petrographic observations buff-painted pottery of Urmia Ware, Kul Tepe of Ajabshir

\begin{tabular}{|c|c|c|c|c|c|c|c|c|c|c|}
\hline $\begin{array}{c}\text { Sample } \\
\text { number }\end{array}$ & Texture & $\begin{array}{c}\text { Quartz } \\
\text { Phenocrysts }\end{array}$ & $\begin{array}{c}\text { Quartz } \\
\text { polycrystalline }\end{array}$ & Plagioclase & $\begin{array}{c}\text { Pyroxene, } \\
\text { Amphibole }\end{array}$ & Mica & Hematite & $\begin{array}{c}\text { Volcanic } \\
\text { Rock }\end{array}$ & M.Rock & Grog \\
\hline 6 & Porphyry & $*$ & $*$ & $*$ & $*$ & - & $*$ & $*$ & $*$ & - \\
\hline 7 & Porphyry & $*$ & $*$ & $*$ & $*$ & $*$ & $*$ & $*$ & - & - \\
\hline 8 & Silt & $*$ & $*$ & $*$ & $\operatorname{tr}$ & - & $*$ & - & $*$ & - \\
\hline 9 & Porphyry & $*$ & $*$ & $*$ & $*$ & $*$ & $*$ & $*$ & $*$ & $*$ \\
\hline 10 & Porphyry & $*$ & $*$ & $*$ & $*$ & $*$ & $*$ & $*$ & - & - \\
\hline
\end{tabular}

شناخته مىشـود و ويـك سـيمتريك و صـافى را نشـان

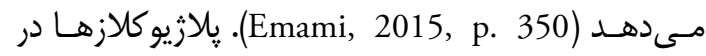

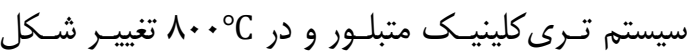

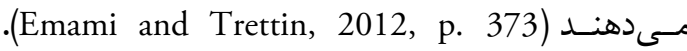

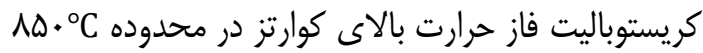
و محدوده يايدارى آن بيش از (2005, p. 223 و يايين شود، تغيير فاز اوليه در دماى

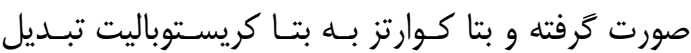
مىشود (Razani, 2013). بنابر اين نمى توان به دليل حضور كانى كريستوباليت در يك نمونه از سفال هاى مطالعه شده از زروه سياه-خاكسترى سنت كورا-رس، بارئ قاطعيت تمام دماى آن را بالا در نظر كرفت. همجنين فاز لابرادوريست در نمونهاي أ و 9 مشاهده مىشود (جدول V-V Table 7). لابرادوريت يك كانى فلدسيار از خانواده پيلازيو كلازهاست كه در حرارتهاى يايين در سيستم ترى كلينيـك متبلـور

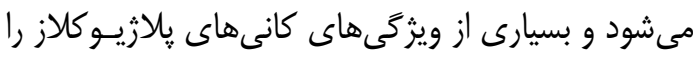
در خود دارد. كه در اغلب مـوارد در سـنــهــاى آذريسن مافيك مانند بازالت، كابرو و نوريت يافت مى گَردد .ايسن

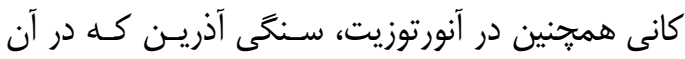

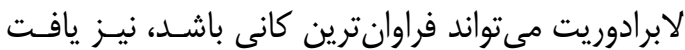

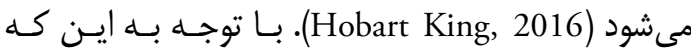
فلدسياتها كانىهــاى شـايع در سـطح يوسـته و مرجـح

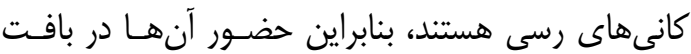

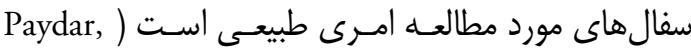
9 (2005, p. 241 شناسايى شده است. سانيدين جزو خانواده فلدسياتهـاى

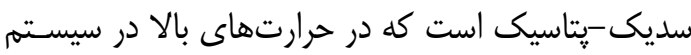
مونو كلينيك متبلور مىشود و به عنوان فاز حرارت بالا در
دوباره بلوجود مى آيند كه به فازهاى ثانويه معروف هستند .(Emami, 2015) با توجه به طيفهاى بلدست آمده از آناليز يراش اشعه

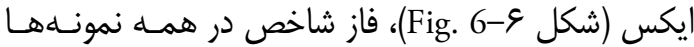

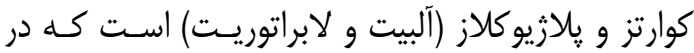

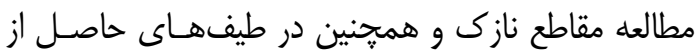
آناليز مادونقرمز تبديل فوريه (جدول م- م-

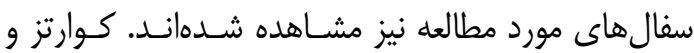

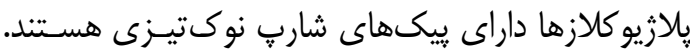
اين مورفولوزى ييك، معرف حضور فازهاى كريستالين در

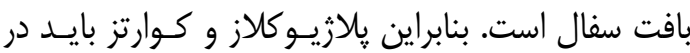

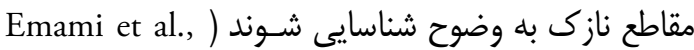
2013). فاز كوارتز در همه نمونهها بر اساس آناليز XRD و FT-IR ومهنين حضور كوارتز در مطالعات مقاطع ناز مشاهده شده است كه به شكل بلورهاى تيز و زاويهدار كه

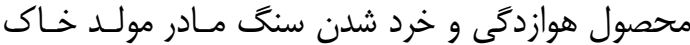

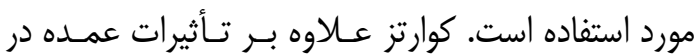
تغييرات كانىشناسانه مرحله يخت، شاخص قابل توجهى

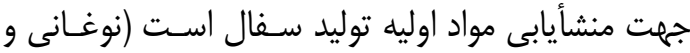
امامى، (وسا). با توجه به تغيير و تبديلات فاز كـوارتز در دماهاى متفاوت، كوارتز شناسايىشده در ايـن نمونـهـهـا

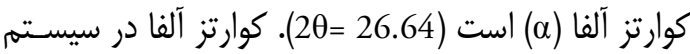
ترى

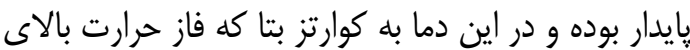

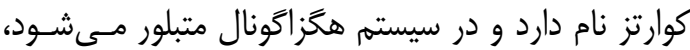

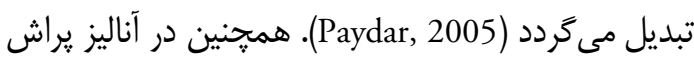
اشعهى ايكس حضور يلازيو كلازهايى نظير آلبيت كه زير

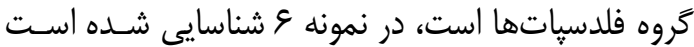
(جدول Table 7-V). آلبيت اكثراً به عنوان يك فرونه فاز اوليـهـ 

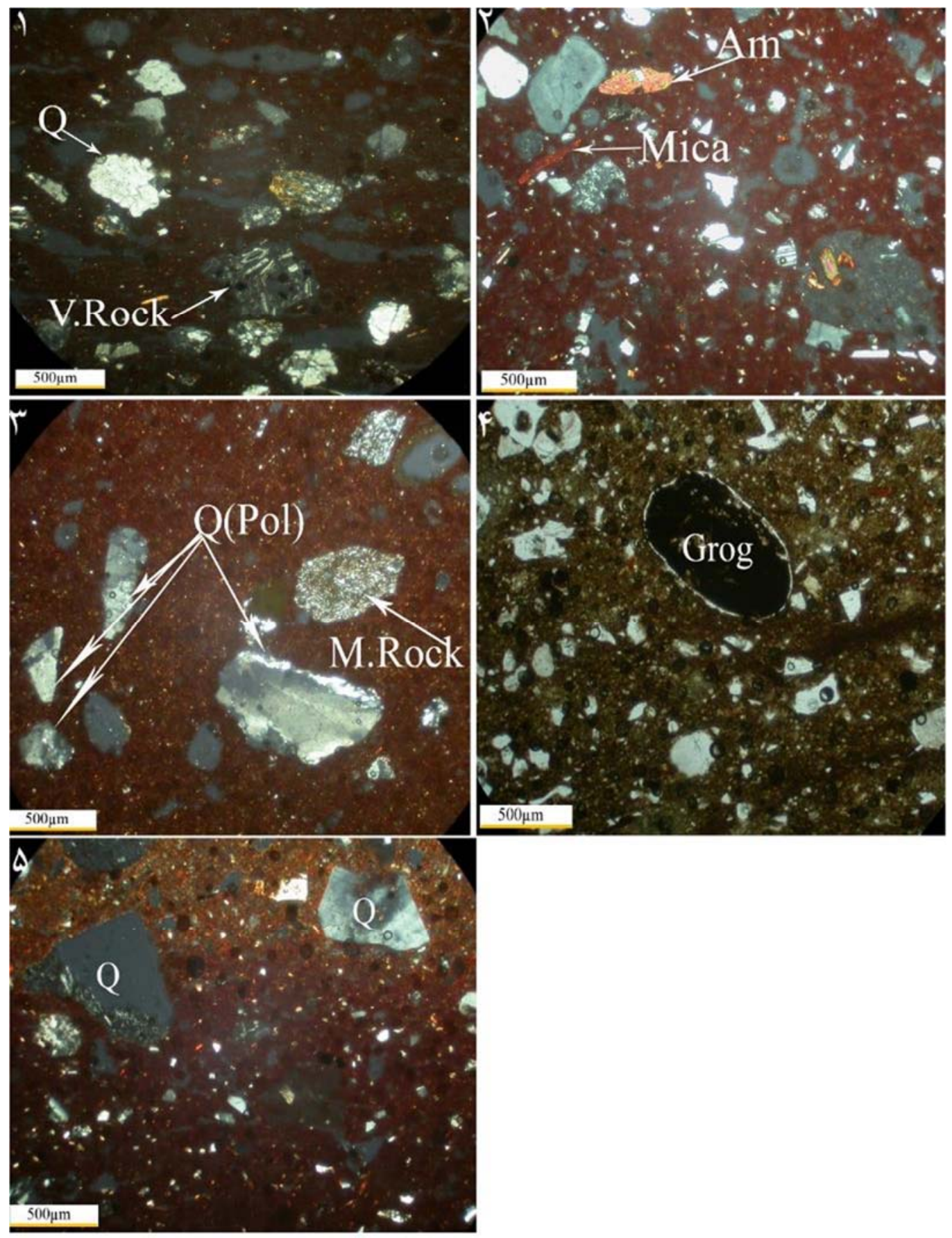

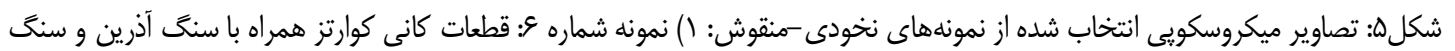

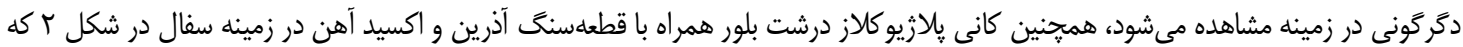

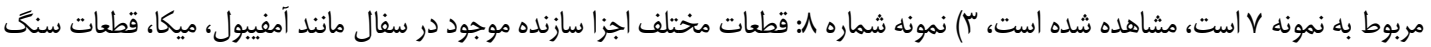

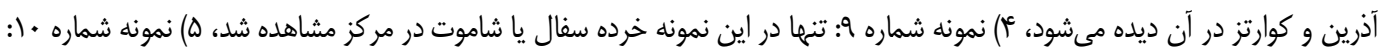

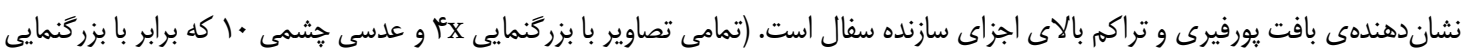

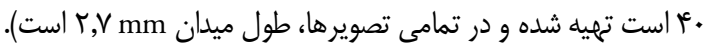

Fig. 5: Microscopic images selected from the samples of buff-painted pottery: 1) Sample No. 6: Quartz mineral V. rock and metamorphic rock can be seen in the pottery Structure, also, mineral Plagioclase, v. rock and iron oxide in the pottery Structure in Figure 2, related to sample 7, 3) sample No.8: Different pieces pottery components such as amphibole, mica and quartz parts V. rock, 4) Sample No.9: In this case, Grog was observed only in the field of pottery, 5) Sample No. 10: Porphyritic texture and high density texture components pottery. (All images Zoom is $x 4$ and that is 10 resisted by zooming eyepiece 40 is provided. In the all images, field of view is $2.7 \mathrm{~mm}$ ). 
جدول V: فازهاى شاخص شناسايى شده در نمونه سفال هاى مورد مطالعه از كؤلتيه عجبشير

Table 7: The Index phases identified in the samples from Kul Tepe of Ajabshir

\begin{tabular}{|c|c|c|}
\hline Sample no. & فازهاى شناسايى شده Phases identified & فرمول شيميايیalical formula \\
\hline 3 سنت كورا-رس (Kura-Araxian) & $\begin{array}{l}\text { Quartz } \\
\text { Sanidin } \\
\text { Anorthoclase } \\
\text { Cristobalit }\end{array}$ & $\begin{array}{l}\mathrm{SiO}_{2} \\
\mathrm{~K}\left[\mathrm{Al} \mathrm{Si}{ }_{3} \mathrm{O}_{8}\right] \\
(\mathrm{Na}, \mathrm{K})\left[\mathrm{AlSi}_{3} \mathrm{O}_{8}\right] \\
\mathrm{SiO}_{2}\end{array}$ \\
\hline سنت كورا-رس (Kura-Araxian) 4 & $\begin{array}{l}\text { Quartz } \\
\text { Anorthite } \\
\text { Labradorite }\end{array}$ & $\begin{array}{l}\mathrm{SiO}_{2} \\
\mathrm{Ca}\left[\mathrm{Al}_{2} \mathrm{Si}_{2} \mathrm{O}_{8}\right] \\
(\mathrm{Na}, \mathrm{Ca})\left[\mathrm{Al} \mathrm{SiO}{ }_{2}\right]\end{array}$ \\
\hline سنت اروميه (Urmian Ware) & $\begin{array}{l}\text { Quartz } \\
\text { Albite } \\
\text { Miccrocline }\end{array}$ & $\begin{array}{l}\mathrm{SiO}_{2} \\
\mathrm{Na}\left[\mathrm{Al} \mathrm{Si}_{3}\right] \mathrm{O}_{8} \\
\mathrm{~K}\left[\mathrm{Al} \mathrm{Si} \mathrm{O}_{8}\right] \\
\end{array}$ \\
\hline سنت اروميه (Urmian Ware) & $\begin{array}{l}\text { Quartz } \\
\text { Sanidin } \\
\text { Labradorite }\end{array}$ & $\begin{array}{l}\mathrm{SiO}_{2} \\
\mathrm{~K}\left[\mathrm{Al} \mathrm{Si} \mathrm{O}_{8}\right] \\
(\mathrm{Na}, \mathrm{Ca})\left[\mathrm{Al} \mathrm{SiO} \mathrm{SiO}_{2}\right]\end{array}$ \\
\hline
\end{tabular}

طيفهاى حاصل از آناليز براش اشعه ايكس بــهـ منظـور

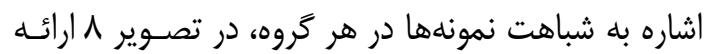

شده است.

\section{\$- أ نتايج آناليز طيفسنجى مادونقرمز تبديل} فوريه (FTIR) نمونههاى مورد مطالعه محوطه كؤلتبه عجبشير

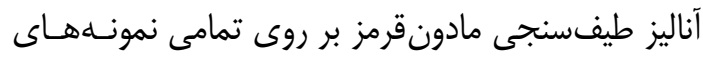

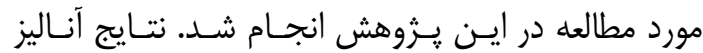
نمونههاى خاكسترى -سياه و نخودى -منقوش، همان كونه

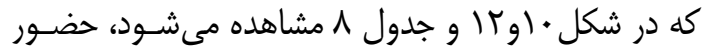

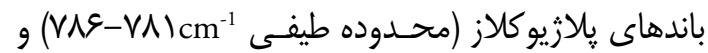
سيليكاتها (محدوده طيفى cm نمونها وجود دارد؛ باند كربندىاكسيد (محسدوده

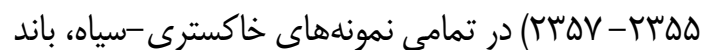

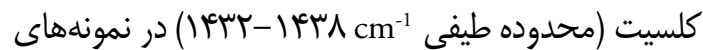
1، ז، س سفال هاى خاكسترى -سياه، باند اورتو كلاز در دو نمونه از سفال هاى نخودى -منقـوش، نمونسهــاى

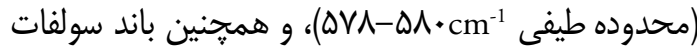

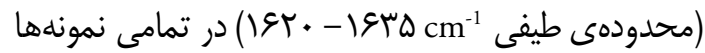
بلجز نمونه V و 1 از نمونههاى نخودى -منقوش شناسايى

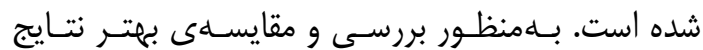

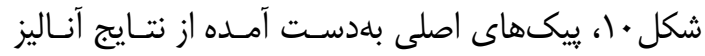

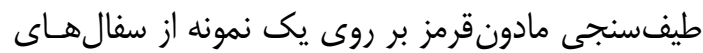
خاكسترى-سياه در شكل 9 مشخص شده شده است.

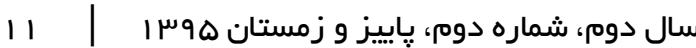

سنگ هاى آتشفشانى يديد مى آيد. همجنين فاز آنورتو كلاز

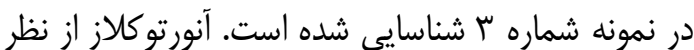

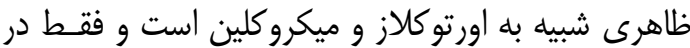
خصوصيات نورى فرق دارد. آنورتوكلاز فلدسباتى است كه مقدار Na $\mathrm{Na}_{2} \mathrm{O}$

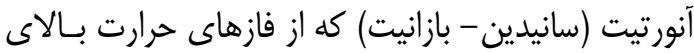

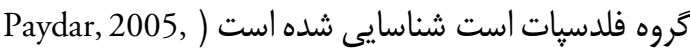

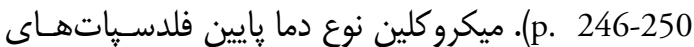
يتاسيمدار با سيستم تبلور ترى كلينيك است كه در طيـف

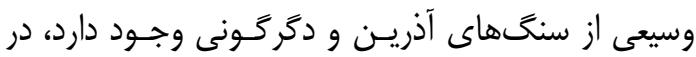

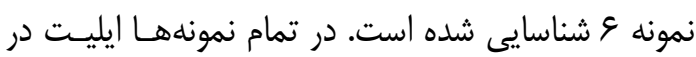

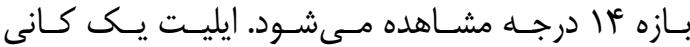
فيلوسيليكاتى، در ارتباط با كروه ميكا و شايعترين كـانى

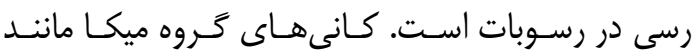

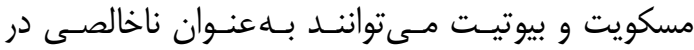
سنحَهاى رسى وجود داشته باشند. آهن موجود در ميكاها سبب تيرهرنح شدن رسها هنكام يخت مى رَردد. ميكـا به علت داشتن قلياها در تركيب شيميايى خود باعث يإيين

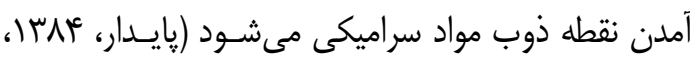

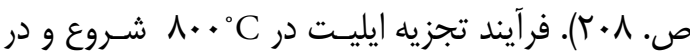

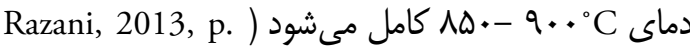

در ادامه از هر گروه نمونه سفالهاى خاكسترى-سياه

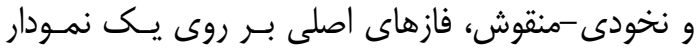

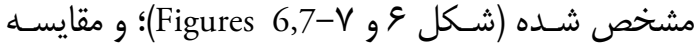




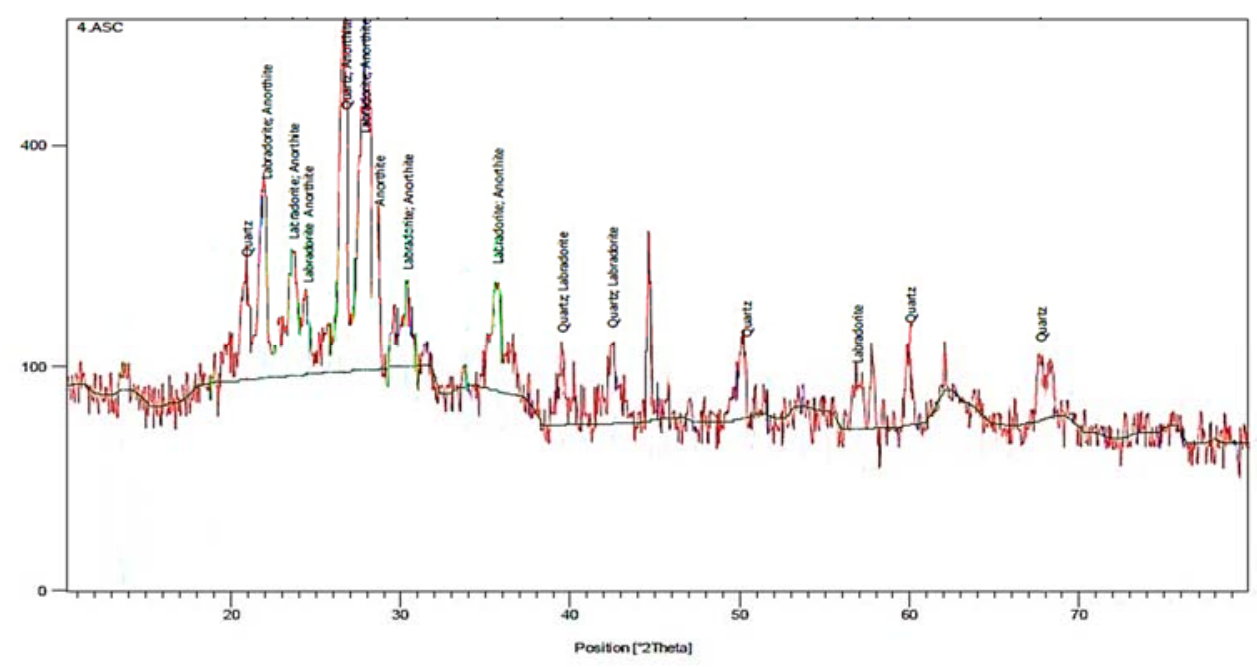

شكل: طيف حاصل از آناليز براش اشعه ايكس نمونه f(سنت كورا-ارس)

Fig. 6: X-ray diffraction spectra of samples 4 (Kura-Arxes)

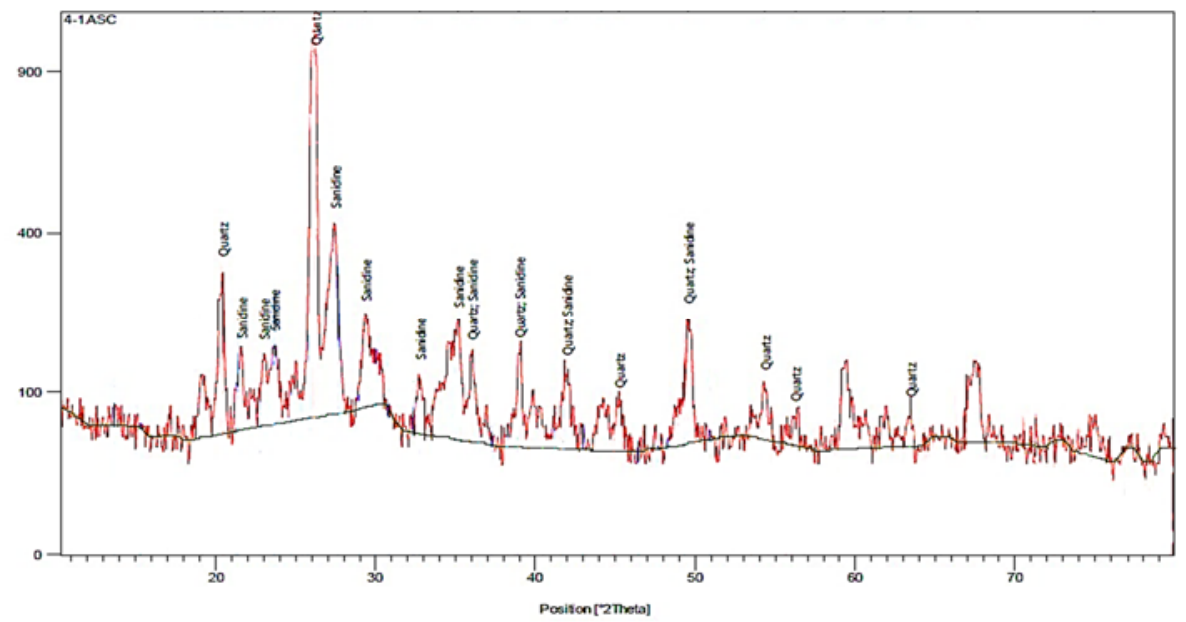

شكل V: طيف حاصل از آناليز براش اشعه ايكس نمونه 9 (سنت اروميه)

Fig. 7: X-ray diffraction spectra of sample 9 (Urmia ware)

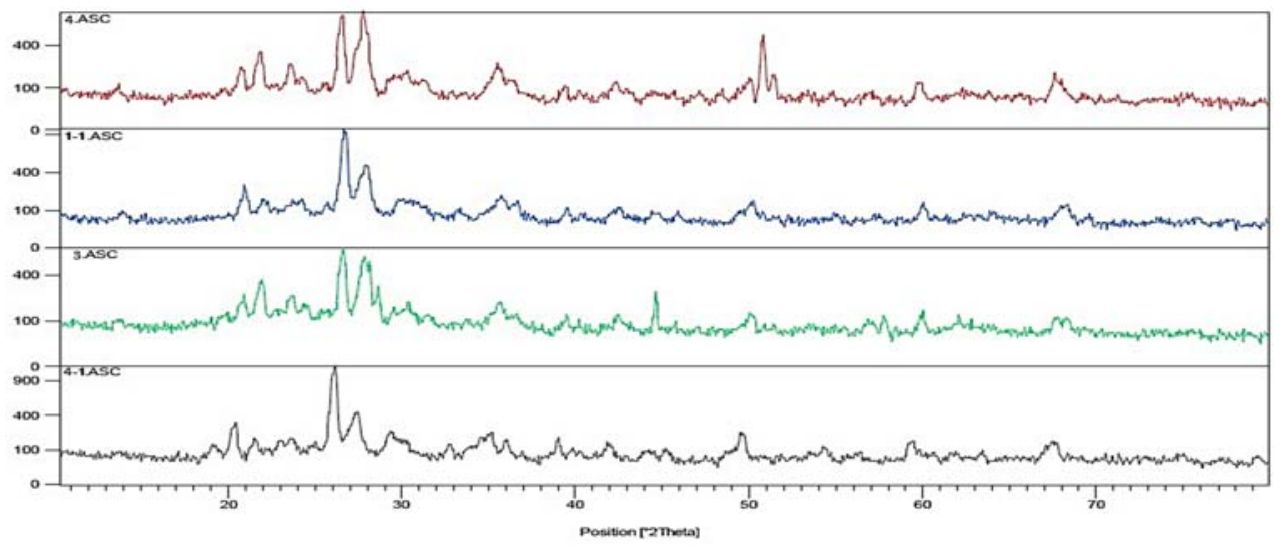

شكلم: مقايسهى طيفهاى حاصل از براش اشعه ايكس نمونه هاى مورد مطالعه

Fig. 8: Comparison of infrared spectra of X-ray diffraction samples 


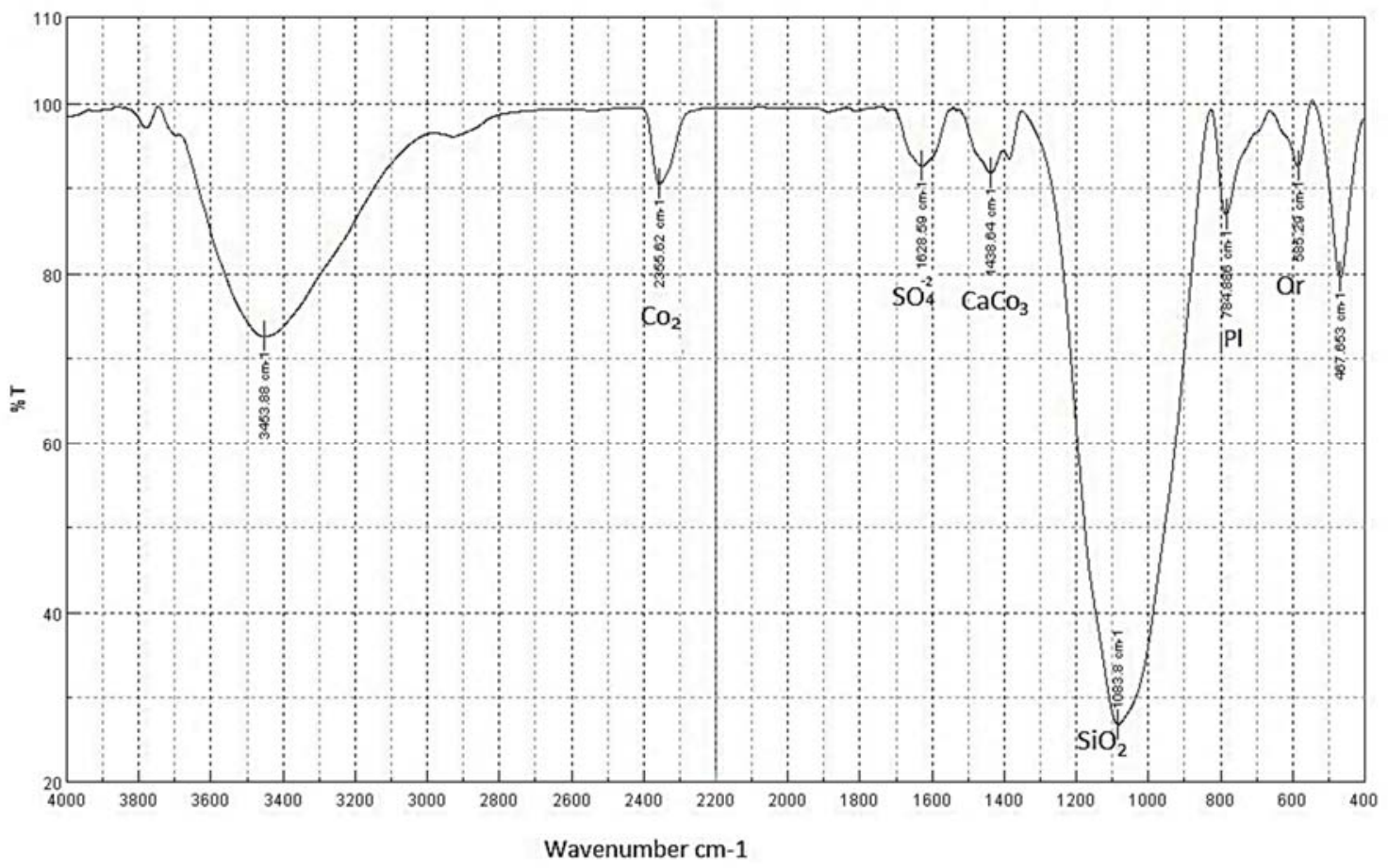

شكلج: طيف حاصل از طيفسنجى مادونقرمز تبديل فوريه نمونه شماره r (سنت كورا-ارس)

Fig. 9: FTIR spectroscopic spectrum of the sample No. 2 (Kura-Araxes)

$$
\text { مشخص شده است. }
$$

بلهمنظور سهولت در بررسى و نشان دادن شـباهت و و

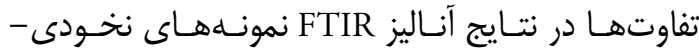

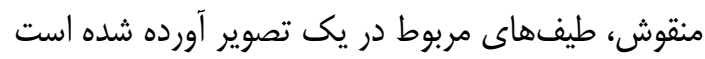

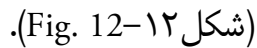

براى سهولت در دستهبندى نتايج آناليز FTIR، ايـن

$$
\text { نتايج در جدول } 1 \text { آورده شده است. }
$$

براى نشان دادن شباهت و تفـاوت در نتـايج آنـاليز

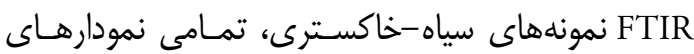
مربوط به آناليز نمونههاى خاكسترى - سياه در يك تصوير سمياه

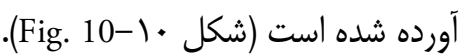

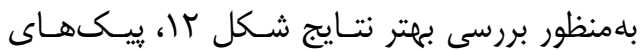

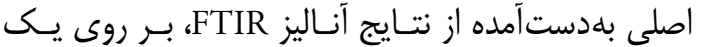

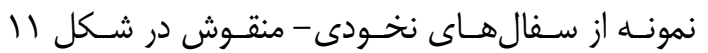

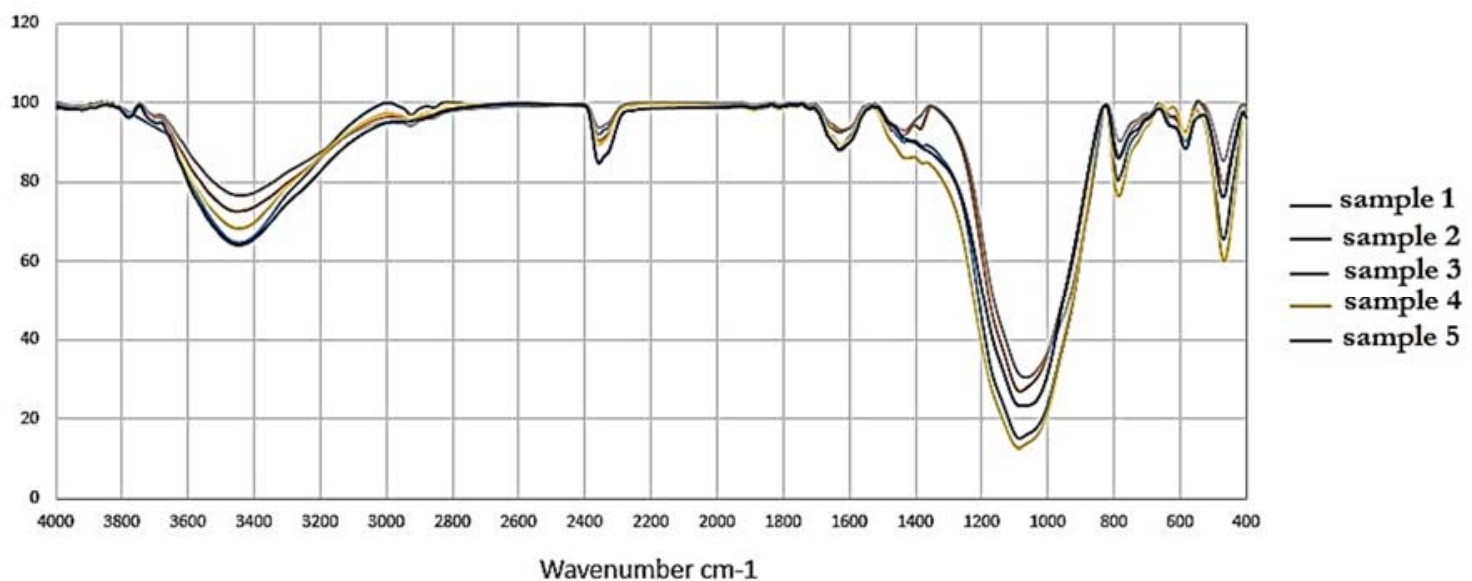

شكل • (: مقايسهى طيفهاى حاصل از آناليز طيفسنجى مادونقرمز نمونهاى سياه-خاكسترى (سنت كورا- ارس)

Fig. 10: FTIR spectroscopic analysis of gray- black samples (Kura-Araxes) 


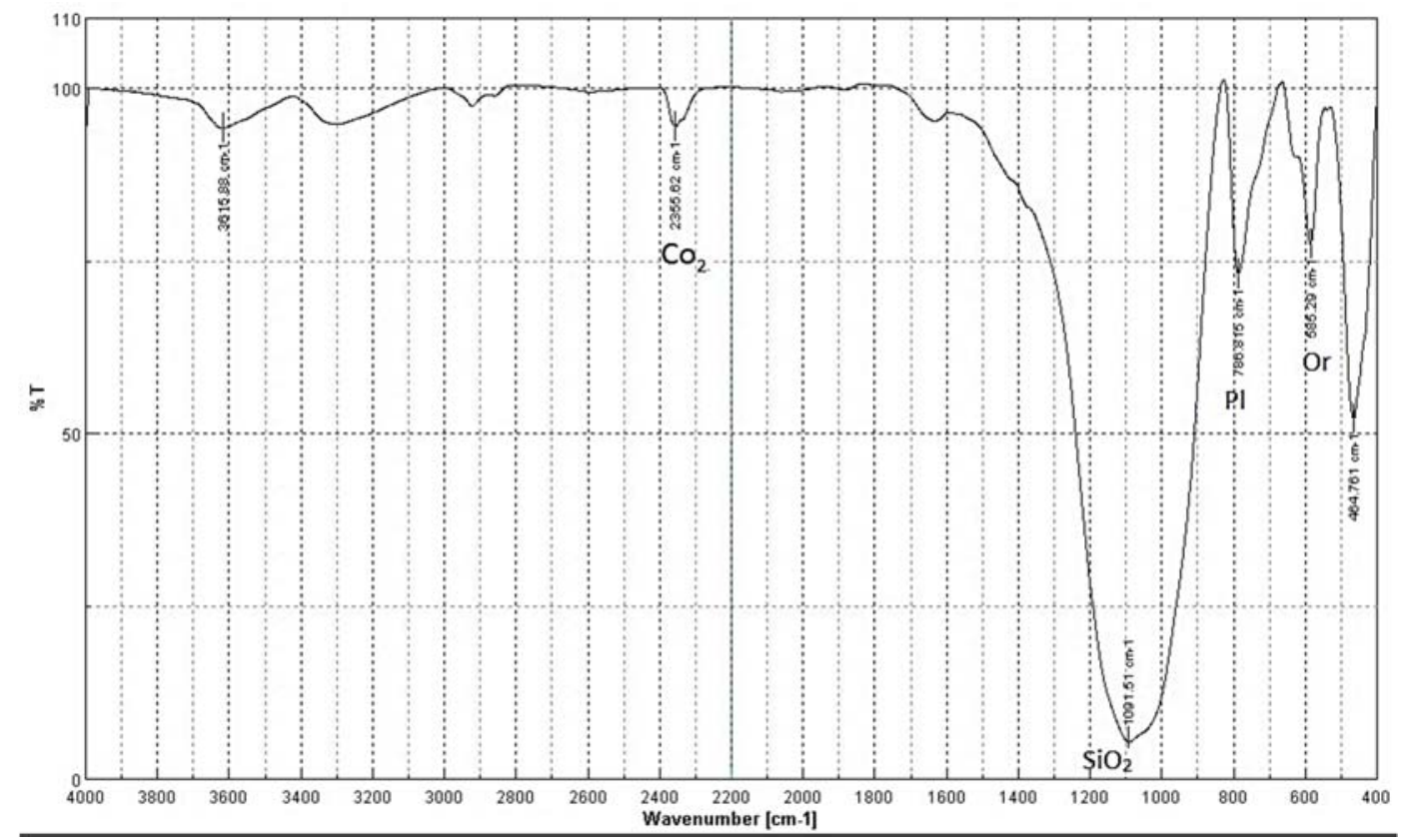

شكل (I: طيف حاصل از طيفسنجى مادونقرمز تبديل فوريه نمونه شماره V (سنت اروميه)

Fig. 11: FTIR spectroscopic spectrum of the sample No. 7 (Urmia ware)

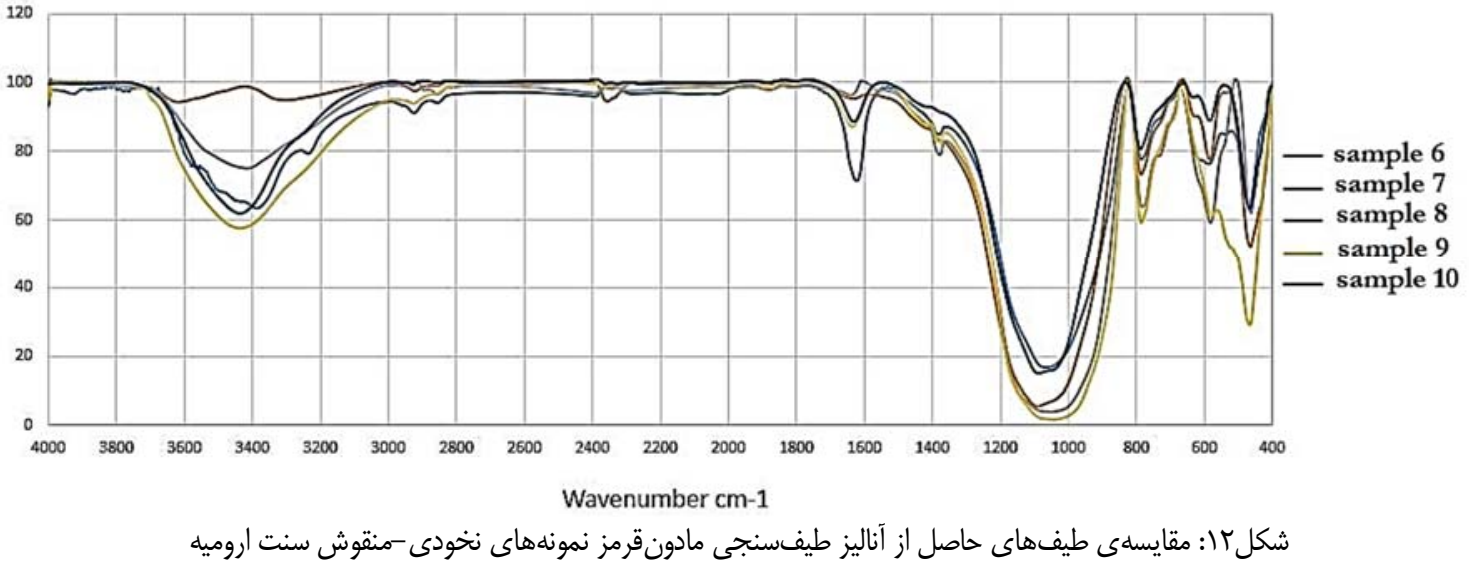

Fig. 12: Comparison of spectra infrared spectroscopic analysis samples of buff-painted pottery of Urmia Ware

$$
\text { جدول م: كانىهاى شناسايى شده در روش طيفسنجى مادونقرمز تبديل فوريه }
$$

Table 8: Minerals identified by the FTIR

\begin{tabular}{|c|c|c|c|c|c|c|}
\hline Sample no. & Calcite & Orthoclase & Plagioclase & Silicate & Sulfate & $\mathrm{CO}_{2}$ \\
\hline 1 & $*$ & - & $*$ & $*$ & $*$ & $*$ \\
\hline 2 & $*$ & - & $*$ & $*$ & $*$ & $*$ \\
\hline 3 & $*$ & - & $*$ & $*$ & $*$ & $*$ \\
\hline 4 & - & - & $*$ & $*$ & $*$ & $*$ \\
\hline 5 & - & - & $*$ & $*$ & $*$ & $*$ \\
\hline 6 & - & $*$ & $*$ & $*$ & $*$ & - \\
\hline 7 & - & $*$ & $*$ & $*$ & - & - \\
\hline 8 & - & - & $*$ & $*$ & - & - \\
\hline 9 & - & - & $*$ & $*$ & $*$ & - \\
\hline 10 & - & - & $*$ & $*$ & $*$ & - \\
\hline
\end{tabular}




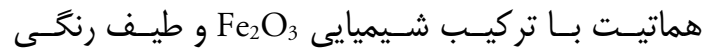

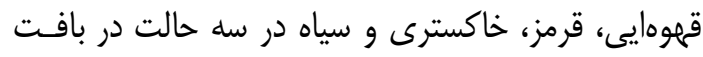

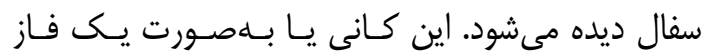
اكسيدى در درجه حرارت پايين كه بيشتر محصول فرآيند

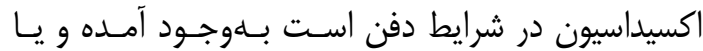
بلهورت يك كانى ثانويه در درجه حرارت بالا در محيط اكسيداسيون در كوره توليد شده است؛ و يا بلصورت ذرات درات دات دات درات Afsharinejad, 2015;) هماتيت در خاك رس موجود است دئ داس Klein et al., 2004

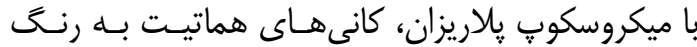

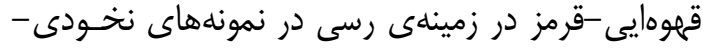

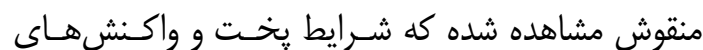
اكسيداسيون عامل اصلى در ايجاد رنغ در آنهاست. بــهـ غير از بحث رنغ سفالهاى مفرغ قــديم در بافت ايـنـ

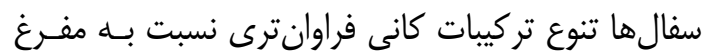

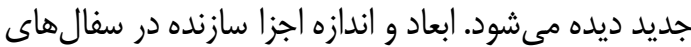

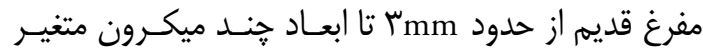

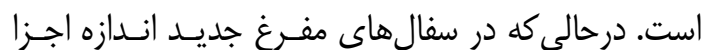

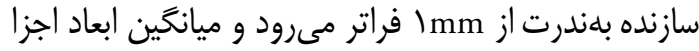

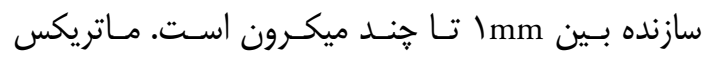
سفالهاى مفرغ قديم از نظر اجزاء تشكيلدهنده ناهمكن بوده و اجزا ريزبلور مختلفى در آنها ديده مى شـود. حسال آن كه از مشخصات سفال هاى مفرغ جديد، زمينه همكَن و يكدست سفالها است كه قطعات درشتبلور اضافه شده،

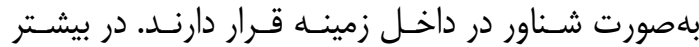
سفال هاى مفرغ قديم كانى كلسيت اوليه ديده مسى شـود؛

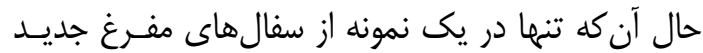
اين كانى وجود دارد كه عدم مشـاهده كلسـيت در ديخــر

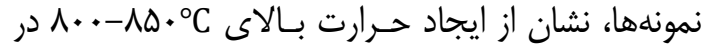

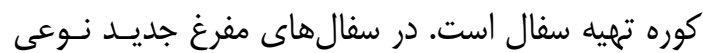

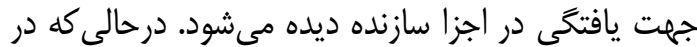

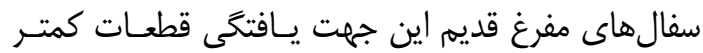

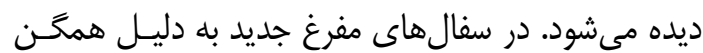
بودن زمينه و اندازه نزديك به هم اجـزا سـازنده، ميـزان فضاى خالى نسبت به سفال هاى مفرغ قديم كمتر است و

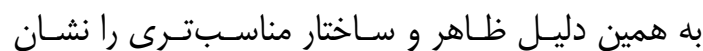
مىدهند. در نهايت مىتوان بيان كرد كـه منطقـهـ مـورد
در آناليز FT-IR حضور باند پِازيوكلاز مشاهده شد، كه زير گروه فلدسياتهاى سديك-كلسيك نظير آلبيت،

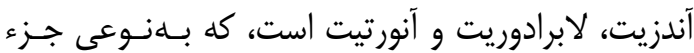

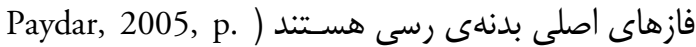

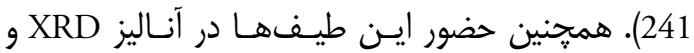

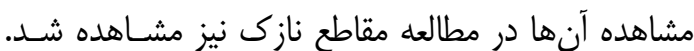
يلازيوكلازها در سيستم ترى كلينيـك متبلـور شـده و در

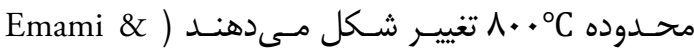
Trettin, 2012, p. 373 ماتريكس سفال، موجب بيشترين تغيير و تبادل در فازهاى

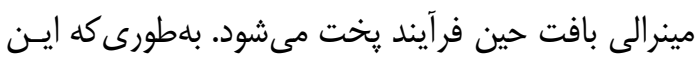

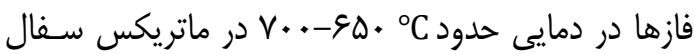
نإيايدار شده و تخريب مىشوند. تجزيـه فـاز كلسـيت در

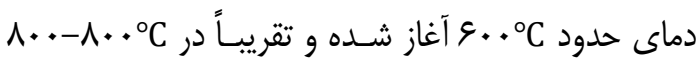
קإيان مى يابد؛ بنـابراين نقـش كربنـات كلسـيم در تعيـين

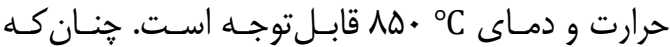

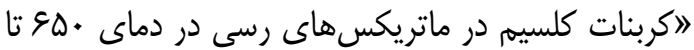

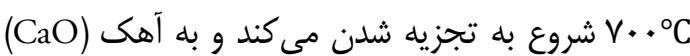
تبديل مىشود. اين فرآيند در دماى Co +. م بيشتر شده و

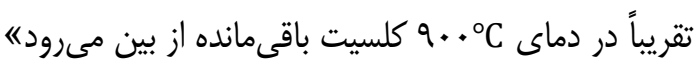
.(Emami, 2013)

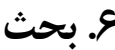

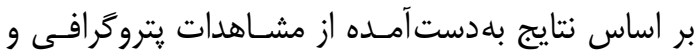
مشاهدهى خرده سفال در شاموت سه نمونه از سفالهاى ناي

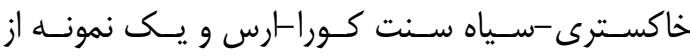

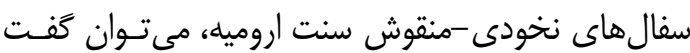

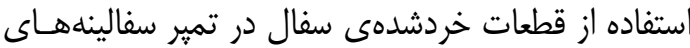

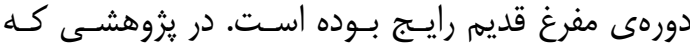

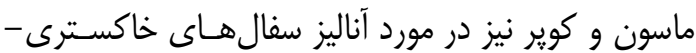
داغدار كورا-رس ناحيهى زاترس مركـزى (تـودين تِّهـ

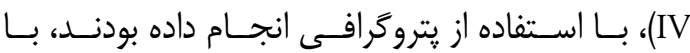
مشاهدهى خردهاى سفال در خميرهى سفالهاى ناحيه زاكرس مركزى، وارداتى بودن آنها را بـر مبنـاى آنـاليز خرده سفالها نشان دادنــ (Mason \& Cooper, 1999). هماتيت (اكسيدآهن III) از ديخر كانى هاى شناسايى شده

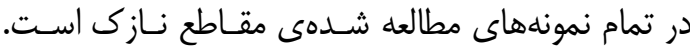


ارس)، و همجنين شناسايى فاز پالازيوكلاز در نتايج آناليز طيفسنجى مادون قرمز تبديل فوريه و همجنـين حضـور

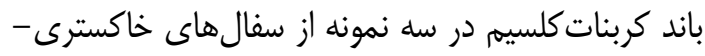

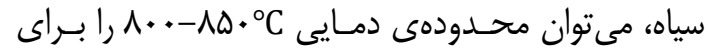
يخت سفال هاى دو دوره در نظر گرفت. در نهايت مى نتوان

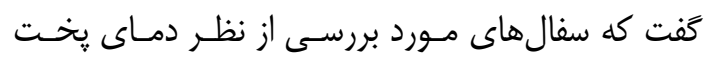
يكسان، اما از نظر شرايط يخت و اتمسفر كوره متفاوتاند.

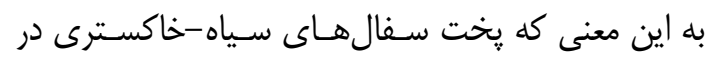

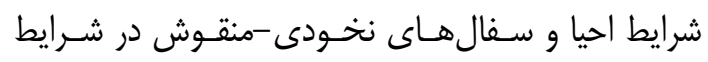
اكسيداسيون تخت شدهاند. به علت شباهت اين دو كَروها

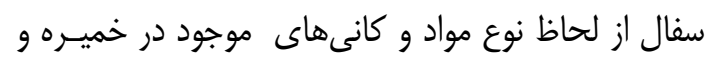

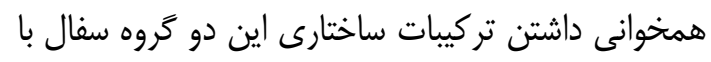

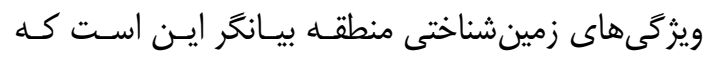

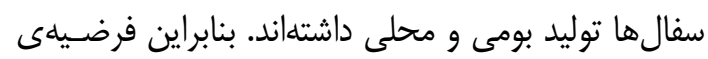

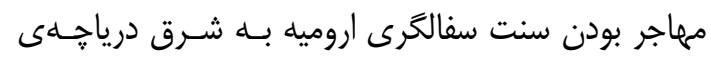

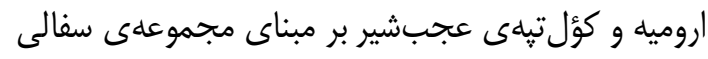
آناليز و مطالعه شده (البته در يكى منطق استقرايى) قابـل تأييد نيست و تحول سفالكرى سنت كورا-رارس بله سنت

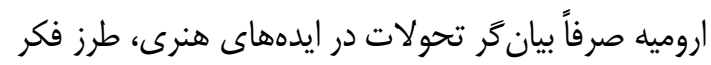
سفالكر و فناورى يخت سفال است.

\section{سياسگَزارى}

مقالهى حاضر، از نتايج يايان نامه كارشناسى ارشد نويسنده

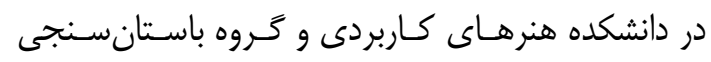

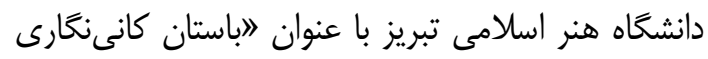

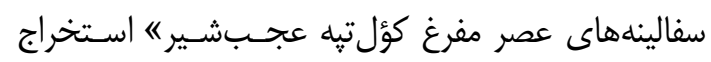

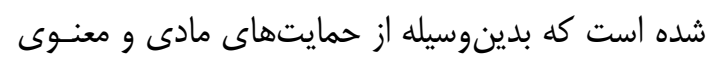

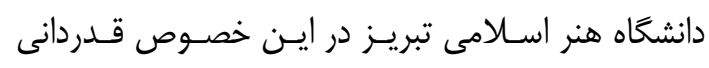

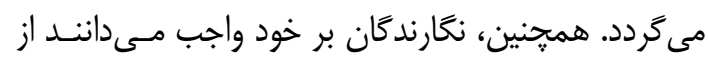

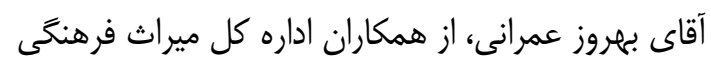

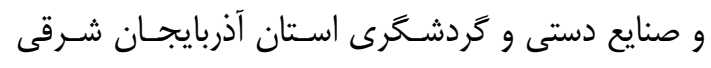

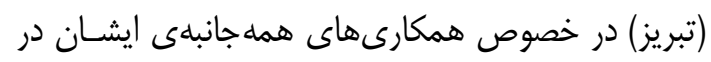
انجام اين يزوهش تقدير و تشكر نمايند.
بررسى (كؤلتبه عجبشير) يوشيده از سنگ هاى مختلف

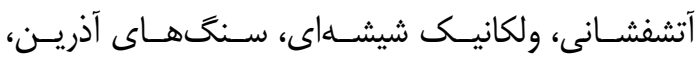

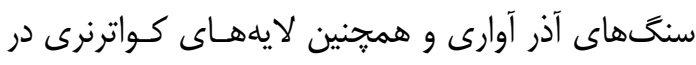

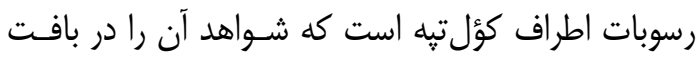

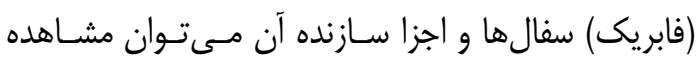

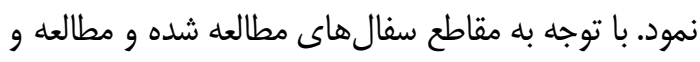
بررسى نقشاهى زمينشناسى منطقه به نظـر مسىرسـد كـهـ،

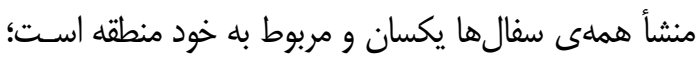

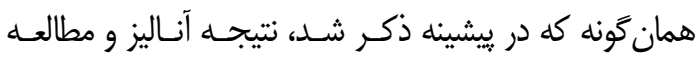

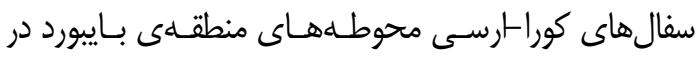

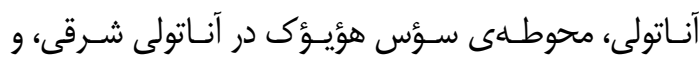

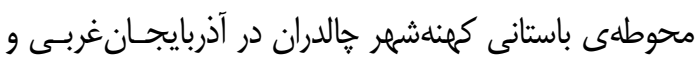

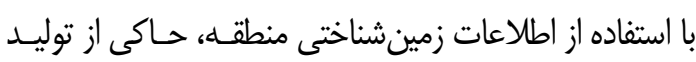

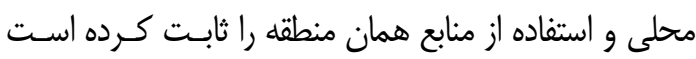
كه در اين يزوهش نيز توليد محلى سفالهاى ســت كـوراارسى و سنت اروميه به اثبات رسيد.

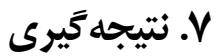

با توجه به مطالعه مقاطع يتروكر افى توسط ميكروسكوب

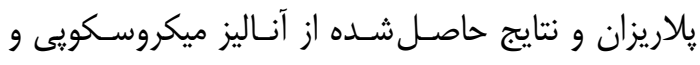
كانى شناختى دو مجموعه سفال مورد مطالعه و تطبيق اين

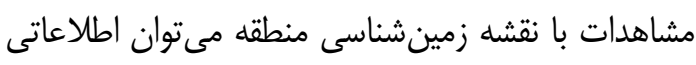
را در مورد خاك مورد استفاده شده در سفالكرى ارائه داد. سفالهاى خاكسترى -سياه و نخـودى -منقــوش از نظـر

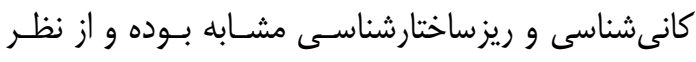

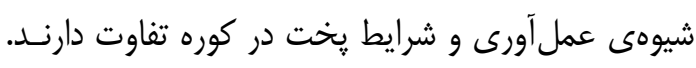

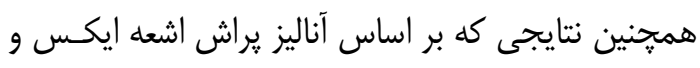

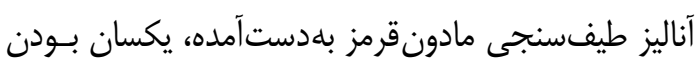

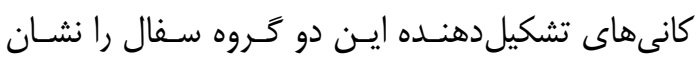

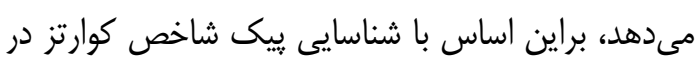

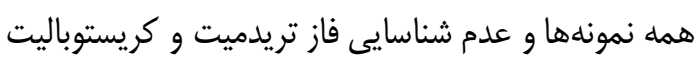

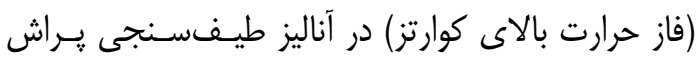

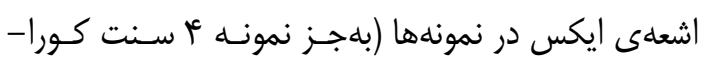




\section{References}

Abedi, A., Shahidi, H. K., Chataigner, C., Niknami, K., Eskandari, N., Kazempour, M., \& Ebrahimi, G. (2014). Excavation at Kul Tepe (Hadishahr), Northwestern Iran, 2010: First Preliminary Report. Ancient near East Studies, 51, 33-165.

Afsharinezhad, H. (2015). The Structural Analysis of the Kura-Araxes Pottery shreds from Kohna Shahar, Chaldiran, West Azerbaijan, Iran. (Unpublished master's Thesis). Department of Archaeometry, Faculty of Applied Arts, Tabriz Islamic Art University. [in Persian]

Afsharinezhad, H.; Ajorloo B.; Jahangiri, A.; Razani, M.; Alizadeh, K. (2017). A Structural Analysis of the Late Early Bronze Age Pottery from Kohna Shahar, West Azerbaijan, Iran. Journal of Archaeological Science, 9(1), 1-17. [in Persian]

Ajorloo, B. (2012). Late Bronze Age and Urmian Ware the Second Millennium B.C. In A. Mosayebzade \& J. Sharifnejad (Eds.), Congress of Hamandishi Shahr-e Irani Tarikhi Farhangi and Mazhabi Urimai, West Azerbaijan: Iranian Academy of the Arts, 1-12. [in Persian]

Ajorloo, B. (2013). The survey of socio- cultural influence of the Kura- Araxes culture (II) on the Iranian central plateau. In I. M. Haciyev (Ed.), Naxçivan Ilkin Şahor va Duzdağ, ANAS, 177-186.

Alizadeh, K., Eghbal, H., \& Samei, S. (2015). Approaches to Social Complexity in KuraAraxes Culture: A view from Kôhne Shahar (Ravaz) in Chaldran, Iranian Azerbaijan. Paléorient, 41(1), 37-54.

Barilaro, D., Barone, G., Crupi, V., Donato, M. G., Majolino, D., Messina, G., \& Ponterio, R. (2005). Spectroscopic techniques applied to the characterization of decorated potteries from Caltagirone (Sicily, Italy). Journal of molecular structure, 744, 827-831.

Batiuk, S. (2000). Petrographic analysis of ETC ceramics from the Bayburt region, North Eastern Anatolia: an exploratory study. Ancient Near Eastern Studies, 37, 153-163.

Burney, C. A., \& Lang, D. M. (1972). The peoples of the hills: Ancient Ararat and Caucasus. Praeger.

Emami, M., \& Trettin, R. (2012). Mineralogical and chemical investigations on the ceramic technology in Čogāa Zanbil, (Iran, 1250 BC). Periodico di Mineralogia, 81(3), 359-377.

Emami, S. M. A. (2015). An Investigation of pottery Technology from 5100 to 4900 BC in the TepeZaghe, (From Micro to Macro). In M. Hesari (Ed.), Tebran, Research Institute of Cultural Heritage and Tourism, 344-355. [in Persian with English abstract]

Emami, S. M. A., Noghani, S. (2013). An Investigation of re- Carbonation Process and
Formation of Secendary Calcite in the Texture of Ancient Potteries by Petrographical Method, Maremat \& Memari-e Iran, 3(5), 55- 67. [in Persian]

Emami, S. M. A., Volkmar, J., \& Trettin, R. (2008). Quantitative characterisation of damage mechanisms in ancient ceramics by quantitative X-ray powder diffraction, polarisation microscopy, confocal laser scanning microscopy and non-contact mode atomic force microscopy. Surface Engineering, 24(2), 129-137.

Kibaroğlu, M., Sagona, A., \& Satir, M. (2011). Petrographic and geochemical investigations of the late prehistoric ceramics from Sos Höyük, Erzurum (Eastern Anatolia). Journal of Archaeological Science, 38(11), 3072-3084.

Klein, M., Jesse, F., Kasper, H. U., \& Gölden, A. (2004). Chemical characterization of ancient pottery from sudan by $\mathrm{x}$-ray fluorescence spectrometry (xrf), electron microprobe analyses (empa) and inductively coupled plasma mass spectrometry (ICP-MS). Archaeometry, 46(3), 339-356.

Mason, R. B., \& Cooper, L. (1999). Grog, petrology, and early Transcaucasia's at Godin Tepe. Iran, 25-31.

Noghani, S., Emami, S. M. A. (2012).

Archaeometry of Historical potteries: Requirements and Methods, Journal of the First Symposium on Materials Science and Conservation of cultural, historical, Tebran: Publishing Research Institute of Cultural Heritage, Handicraft and Tourism in collaboration with Research materials and energy, 505- 524. [in Persian]

Paydar, H. (2005). The raw material used in the ceramics industry. Isfahan: Gazal publications. [in Persian]

Razani, M., Ajorloo, B., Haery, A., \& Tirandaz, A. (2013). Archaeometrica studies on the Qaradagh Islamic Potteries, Tabriz Islamic Art University, Research Project, No, 8195. Tabriz Islamic Art University. [in Persian]

Stuart, B. H. (2007). Analytical techniques in materials conservation. John Wiley \& Sons.

Tala'i, H. (1984). Notes on New Pottery Evidence from the Eastern Urmia Basin: Gol Tepe. Iran Richmond, 22, 151-156.

Tala'i, H. (2006). The Bronze Age of Iran, First Edition, Tehran: Samt publications. [in Persian]

Tala'i, H. (2013). Eight thousand years of Iran pottery, Second Edition, Tehran: Samt publications. [in Persian] 